\title{
MURAWY PIASKOWE ZE ZWIAZZKU SILENO CONICAE-CERASTION SEMIDECANDRI KORNECK 1974 NA TERENIE KAMPUSU UAM MORASKO W POZNANIU
}

\author{
ANDRZEJ BRZEG, TOMASZ SZYGENDOWSKI \\ Zakład Ekologii Roślin i Ochrony Środowiska, Wydział Biologii, \\ Uniwersytet im. Adama Mickiewicza w Poznaniu, \\ ul. Umultowska 89, 61-614 Poznań
}

\begin{abstract}
Field studies on anthropogenic psammophilous swards of the Sileno conicae-Cerastion semidecandri alliance were carried out in the years 2015-2016 in the area of the Adam Mickiewicz University Morasko campus in Poznań, Poland. As a result of a classical table analysis of phytosociological data, five associations were distinguished. The relevés have been arranged with the use of PCA and CCA ordination methods to study the overall variability of the examined communities and their position along some environmental gradients. In the paper, issues concerning successional dynamics and the synsystematical position of swards of the studied type, are also raised.
\end{abstract}

Keywords: Sileno conicae-Cerastion semidecandri, ephemeral psammophilous swards, early spring aspect, Adam Mickiewicz University Morasko campus, Poznań, Poland

\section{WSTĘP}

Związek Sileno conicae-Cerastion semidecandri obejmuje wybitnie antropogeniczne, pionierskie, wyspecjalizowane zbiorowiska roślinne porastające rozmaite podłoża piaszczysto-żwirowe - nowo powstałe lub/i poddawane okresowym zaburzeniom. Fitocenozy należących do niego zespołów mają fizjonomię niskich muraw, których najistotniejszy pod względem diagnostycznym element stanowią drobne, w większości biało kwitnące terofity, głównie z rodzin Brassicaceae i Caryophyllaceae, tworzące charakterystyczny aspekt wczesnowiosenny (Ratyńska i in. 2010).

Po raz pierwszy związek Sileno conicae-Cerastion semidecandri opisał Korneck (1974) z obszaru Nadrenii, umieszczając go w rzędzie Festuco-Sedetalia acris w ramach klasy Sedo-Scleranthetea. Zaliczył do niego trzy jednostki rangi podstawowej: nowo opisane zespoły Bromo tectorum-Phleetum arenarii i Sileno conicae-Cerastietum semidecandri oraz zbiorowisko z Mibora minima. Jako główne gatunki charakterystyczne związku wskazał Cerastium semidecandrum, Phleum arenarium i Silene conica, a jako wyróżniający Bromus tectorum. Podkreślił jednocześnie ważną rolę innych terofitów, m.in.: Arenaria serpyllifolia, 
Erophila verna, Holosteum umbellatum, Medicago minima i Myosotis stricta, które traktował jako gatunki diagnostyczne klasy. Ujęcie to zostało potwierdzone w obszerniejszej monografii dotyczącej roślinności południowych Niemiec (Korneck 1978). W Polsce zbiorowiska omawianego typu należą do słabo udokumentowanych (Brzeg, Wojterska 1996, 2001). Pierwszy zwrócił na nie uwagę Głowacki (1988), który, opisując z Wysoczyzny Siedleckiej nowy zespół Cerastio semidecandri-Androsacetum septentrionalis, proponował umieszczenie interesującego nas związku w osobnym, prowizorycznym rzędzie Cerastietalia semidecandri w ramach klasy Sedo-Scleranthetea. Wcześniej ten autor (1984) udokumentował ze Wzgórz Dalkowskich stanowiska bardzo podobnych fitocenoz z Androsace septentrionalis, ujmując je w randze wariantu zespołu Sileno otitae-Festucetum Libb. 1933.

Zdecydowanie najbogatszy materiał, dotyczący omawianego typu muraw, pochodzi z późniejszych dziesięcioleci z terenu Wielkopolski. Badali je tam m.in.: Rakowski (1996), Brzeg i Janyszek (1998), Ratyńska (2001), Wojterska (2003) i Skrzypczak (2007). Pojedyncze zdjęcia fitosocjologiczne prezentowali także inni autorzy.

W ostatnich latach bardzo liczne i miejscami rozległe płaty muraw interesującego nas związku zaobserwowano na obszarze kampusu Uniwersytetu im. Adama Mickiewicza Morasko w Poznaniu. Celem niniejszego artykułu jest zaprezentowanie zebranych materiałów dotyczących tych muraw i próba interpretacji ich zróżnicowania.

\section{TEREN BADAŃ}

Kampus UAM Morasko położony jest w północnej części Poznania (ryc. 1). Rozciąga się na obszarze dwóch osiedli: Morasko-Radojewo (część zachodnia) i Umultowo (część wschodnia). Rozleglejsza jest część zachodnia, na której znajduje się większość budynków poszczególnych wydziałów (ryc. 2). W części wschodniej ulokowane są jedynie budynki i tereny Wydziału Nauk Geograficznych i Geologicznych oraz kompleksu sportowego.

Budowa kampusu UAM została zaplanowana na terenach wcześniej użytkowanych rolniczo. Kolejno oddawano do użytku budynki (Kampus Morasko 2017): Wydziału Fizyki (1994-1999), Wydziału Matematyki i Informatyki (2002), Wydziału Biologii oraz Wydziału Nauk Politycznych i Dziennikarstwa (2004), Wydziału Nauk Geograficznych i Geologicznych (2004-2006), kompleksu sportowego (2010), Wydziału Chemii (2012), Wydziału Historycznego oraz Wielkopolskiego Centrum Zaawansowanych Technologii (2015). Pomiędzy budynkami wysiano trawniki, które są regularnie koszone, wytyczono utwardzone parkingi, drogi dojazdowe i piesze, systematycznie prowadzone są punktowe lub drobnopowierzchniowe prace ziemne związane $\mathrm{z}$ nasadzaniem 


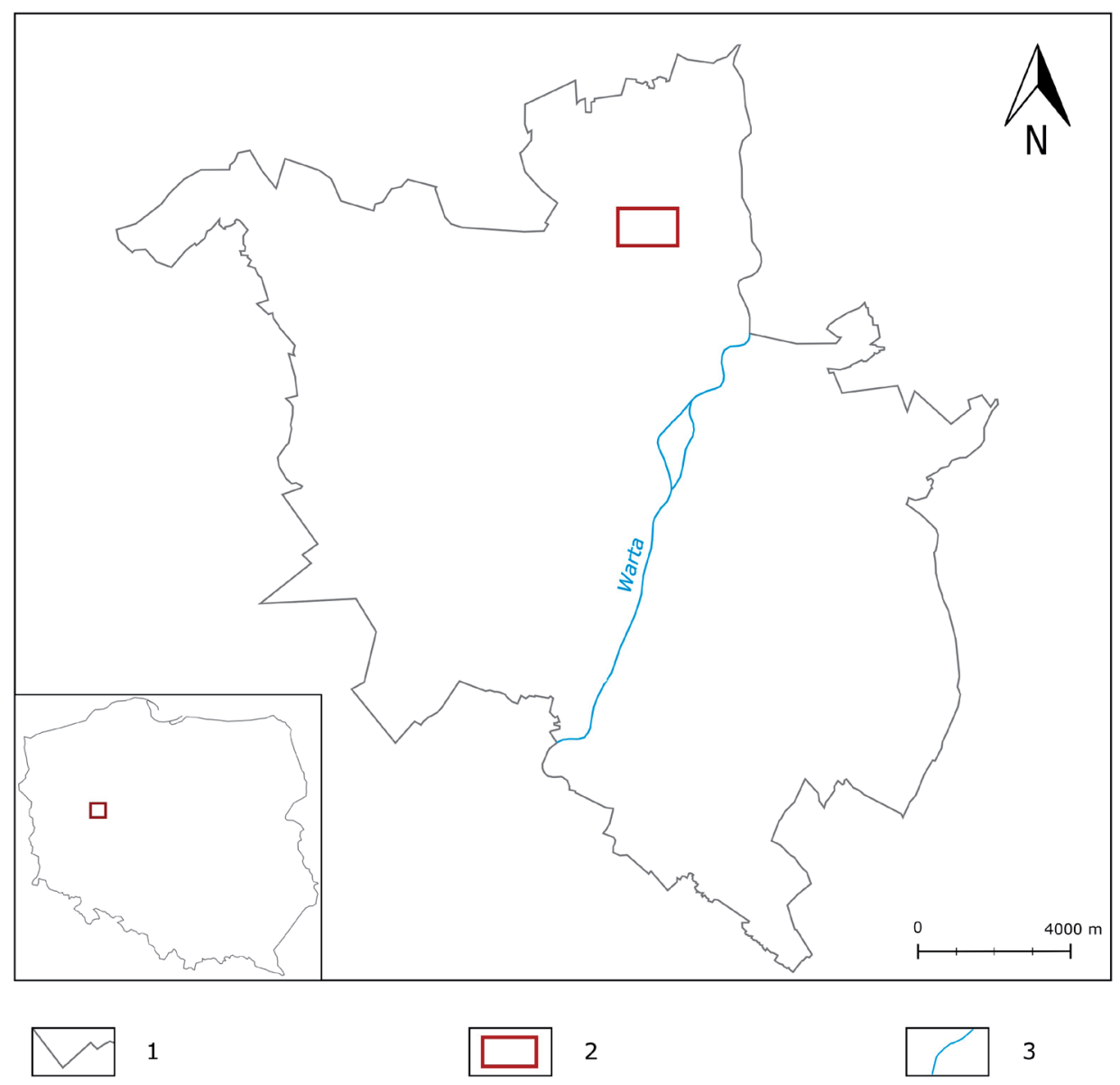

Ryc. 1. Położenie kampusu UAM Morasko w granicach Poznania 1 - granica miasta, 2 - teren kampusu UAM, 3 - rzeka

Fig. 1. Localization of the Adam Mickiewicz University Morasko campus in Poznan 1 - city border, 2 - area of the campus, 3 - river

drzew, krzewów ozdobnych, zakładaniem kwietników itp. W kilku miejscach pozostawiono skupienia spontanicznych zapustów drzew lekkonasiennych (brzozy, osiki, sosny czy wierzb).

Według regionalizacji fizyczno-geograficznej Polski (Kondracki 1998) interesujący nas teren wchodzi w skład mikroregionu Wzgórz Owińsko-Kierskich, mezoregionu Pojezierza Poznańskiego, makroregionu Pojezierza Wielkopolskiego, Podprowincji Pojezierzy Południowobałtyckich i Prowincji Niżu Środkowoeuropejskiego. Zgodnie z klasyfikacją regionów geobotanicznych Polski (Matuszkiewicz 1993) obszar badań stanowi część Podokręgu Chludowskiego 


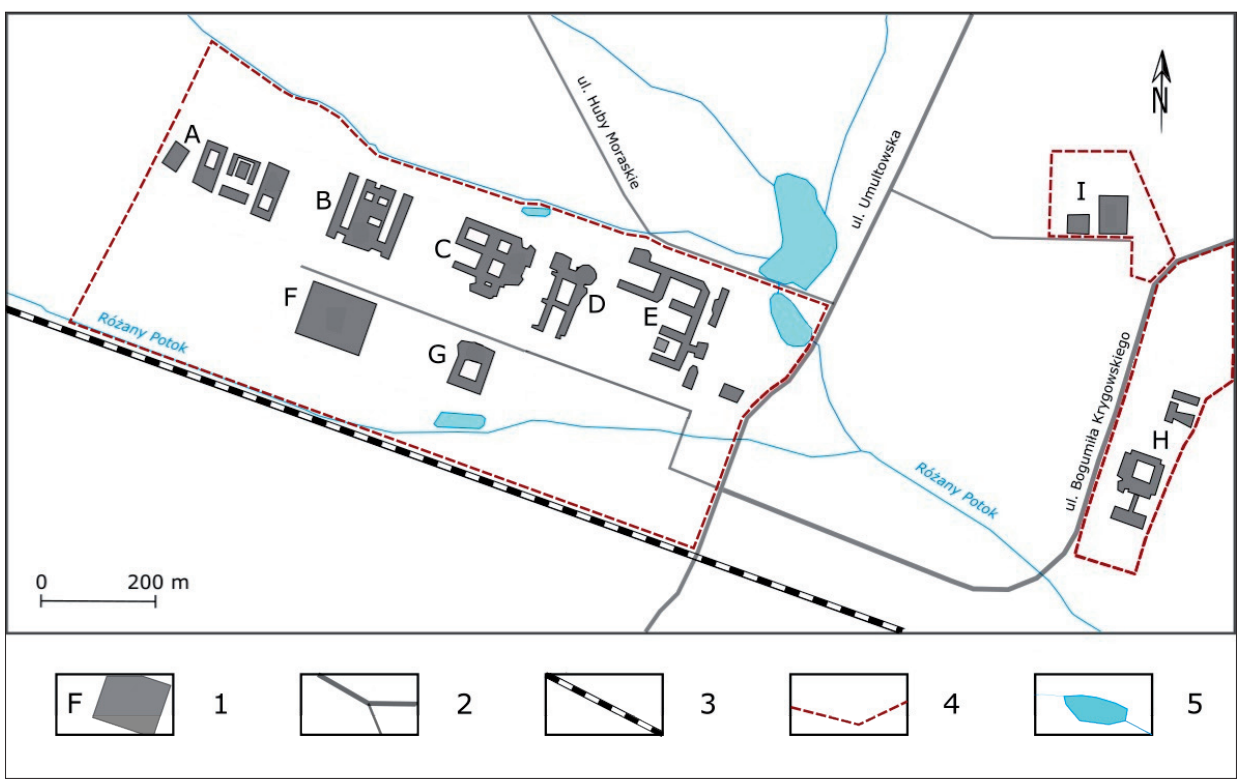

Ryc. 2. Mapa obszaru kampusu UAM Morasko

1 - budynki wydziałów: A - Wielkopolskie Centrum Zaawansowanych Technologii, B - Wydział Chemii, C - Wydział Biologii, D - Wydział Matematyki i Informatyki, E - Wydział Fizyki, F - Wydział Histoyczny, G - Wydział Nauk Politycznych i Dziennikarstwa, H - Wydział Nauk Geograficznych i Geologicznych, I - kompleks sportowy; 2 - główne drogi, 3 - linia kolejowa, 4 - granica obszaru badań, 5 - zbiorniki i cieki wodne

Fig. 2. Map of the Adam Mickiewicz University Morasko campus

1 - buildings of faculties; 2 - major roads, 3 - railroad, 4 - study area boundary, 5 - water bodies and water courses

w ramach Okręgu Poznańskiego, Krainy Notecko-Lubuskiej i Działu Brandenbursko-Wielkopolskiego.

Poznań położony jest w strefie klimatu umiarkowanego ciepłego, przejściowego między morskim a kontynentalnym. Średnia roczna temperatura za lata 1971-2000 wynosi $8,3^{\circ} \mathrm{C}$, wieloletnia średnia roczna suma opadów atmosferycznych nie przekracza $530 \mathrm{~mm}$ (Farat i in. 2004), średnia liczba godzin nasłonecznienia rzeczywistego w ciągu roku sięga 1515 (wartość za lata 1961-1990; Farat 1996), a okres wegetacyjny trwa przeciętnie 225 dni (Żmudzka 2012).

Kampus zlokalizowany jest na obszarze tzw. sandru naramowickiego, powstałego na przedpolu moreny czołowej stadiału poznańskiego z położoną nieco na zachód kulminacją Góry Moraskiej. Sandr charakteryzuje się prawie płaską powierzchnią, nachyloną minimalnie w kierunkach zbliżonych do południowego (Klimko i in. 2008; Krygowski 1958).

Badany teren odwadniają trzy cieki wodne: Różany Potok, będący lewostronnym dopływem Warty, oraz dwa cieki o charakterze okresowym. Wśród 
wód powierzchniowych obszaru wymienić należy również cztery stawy retencyjne (Zawadzka 2009).

Według mapy rolniczo-glebowej z lat 70. XX w. (Zawadzka 2009, 2015) najbardziej rozpowszechnionym podtypem gleb na obszarze obecnego kampusu były gleby brunatne wyługowane, wytworzone z piasków słabogliniastych, rzadziej z glin lekkich. Na północno-zachodnich obrzeżach omawianego terenu występowały gleby bielicowe właściwe i rdzawe, powstałe z piasków gliniastych lekkich. W północno-zachodniej części kampusu spotyka się czarne ziemie właściwe, a wzdłuż jednego z cieków okresowych oraz w dolinie Różanego Potoku stwierdzono obecność gleb murszowych i murszowatych. W wyniku prowadzonych ostatnio na szeroką skalę prac ziemnych i budowlanych znaczącą i stale rosnącą powierzchnię w obrębie interesującego nas terenu zajmują gleby urbanoziemne o charakterze arenosoli antropogenicznych.

Na obszarze dzisiejszego kampusu nie prowadzono dotychczas szczegółowych badan flory, udokumentowano jednak w jego pobliżu ostoje cennych i rzadkich roślin. Do tych ostoi należą m.in. rezerwat „Meteoryt Morasko” i projektowany rezerwat „Kokoryczowe Wzgórze” w Radojewie. Liczne osobliwości florystyczne podawano również ze znajdującej się w obrębie kampusu doliny Różanego Potoku (Borysiak, Stachnowicz 2003).

Roślinność rzeczywistą rejonu Moraska, Radojewa i Umultowa scharakteryzowali w swym opracowaniu Borysiak i Stachnowicz (2003), stwierdzając łącznie 155 zespołów zaliczanych do 21 klas, 29 rzędów i 50 związków. W obrębie samego kampusu badania fitosocjologiczne prowadzili dotychczas m.in.: Balcerkiewicz (2006), Brzeg (2007, 2009), Balcerkiewicz i Pawlak (2012) oraz Zawadzka (2015).

\section{MATERIAŁ I METODY}

Oryginalny materiał stanowi 38 zdjęć fitosocjologicznych wykonanych metodą Braun-Blanqueta (Braun-Blanquet 1964) w latach 2015 i 2016 na terenie kampusu UAM Morasko w Poznaniu (ryc. 2). Po tradycyjnej analizie tabelarycznej, popartej analizą składowych głównych (PCA), zestawiono je w pięciu tabelach analitycznych (tab. 1-5). W celu wskazania głównych kierunków zróżnicowania badanych muraw wzdłuż gradientów środowiska powyższy materiał poddano także kanonicznej analizie zgodności (CCA) z zastosowaniem ekologicznych liczb wskaźnikowych Ellenberga (1974, uzupełnionych danymi Zarzyckiego i in. 2002, przekształconymi do skali dziewięciostopniowej) jako zmiennych siedliskowych. Uwzględniono następujące wskaźniki: światła (L), temperatury $(\mathrm{T})$, kontynentalizmu $(\mathrm{K})$, wilgotności $(\mathrm{F})$, odczynu podłoża $(\mathrm{R})$ 
i azotu (N). W analizach numerycznych użyto pakietu ordynacyjnego CANOCO 5 (ter Braak i Šmilauer 2014).

W zbiorczej tabeli udokumentowanych zbiorowisk dla całego obszaru Wielkopolski (tab. 6), w której frekwencję podano w procentach, zestawiono łącznie 101 zdjęć, w tym 63 innych autorów.

Nomenklatura i ujęcie podstawowych jednostek syntaksonomicznych zgodne są z przeglądem Ratyńskiej i in. (2010). Nazewnictwo roślin naczyniowych przyjęto za Mirkiem i in. (2002), mchów za Ochyrą (2003), a porostów za Fałtynowiczem (2008). Nowe syntaksony opisano według przepisów Międzynarodowego Kodeksu Nomenklatury Fitosocjologicznej (ICPN, Weber i in. 2000).

Fizjonomię badanych muraw udokumentowano za pomocą fotografii.

\section{WYNIKI}

\section{Przegląd systematyczny badanych muraw}

W wyniku przeprowadzonych badań terenowych i analiz kameralnych stwierdzono, że na terenie kampusu UAM Morasko w Poznaniu występują fitocenozy aż pięciu jednostek rangi podstawowej badanych muraw, z których część wykazuje także dalsze zróżnicowanie wewnętrzne. Przegląd systematyczny wyróżnionych syntaksonów przedstawiono poniżej.

Cl. Koelerio-Corynephoretea Klika in Klika et Novak 1941

O. Corynephoretalia canescentis Klika 1934 (incl. Thero-Airetalia Oberd. in Oberd. et al. 1967, Festuco-Sedetalia acris R.Tx. 1951 p.p., Veronico-Arabidopsietalia Pass. 1977, Cerastietalia semidecandri Głowacki 1988 nom. inval. (Art. 2b ICPN); non Sedo-Scleranthetalia Br.-Bl. 1955)

All. Sileno conicae-Cerastion semidecandri Korneck 1974 (non Arabidopsion thalianae Pass. 1964 sensu Sádlo et al. 2007 nom. ambig. propos.; incl. Valerianello-Veronicion arvensis Pass. 1995)

Ass. Cerastio semidecandri-Androsacetum septentrionalis Głowacki 1988 ex Brzeg et M. Wojterska 2001

Subass. C.s.-A.s. typicum Brzeg et Szygendowski 2017 subass. nova Subass. C.s.-A.s. thymetosum serpylli Brzeg et Szygendowski 2017 subass. nova Ass. Myosotido strictae-Arabidopsietum thalianae Pass. (1962) 1977 Ass. Arenario-Sedetum acris (Hallberg 1971) Pass. 1977 (incl. Rumici tenuifolii-Sedetum acris Pass. 1977)

Ass. Erodio-Senecionetum vernalis Lührs 1993 (=Myosotido-Erodietum cicutarii Pass. 1996, incl. typus)

Ass. Sileno conicae-Cerastietum semidecandri Korneck 1974 


\section{Charakterystyka wyróżnionych zespołów}

\section{Cerastio semidecandri-Androsacetum septentrionalis \\ (tab. 1; tab. 6, kol. 1-2)}

Ch. Ass. (reg.): Androsace septentrionalis; D. Ass. (reg.): Calamagrostis epigejos, Pinus sylvestris

Struktura i skład florystyczny. Fitocenozy zespołu naradki północnej i rogownicy pięciopręcikowej, jako jedyne z badanych, odznaczają się strukturą trójwarstwową. Słabo zwartą warstwę krzewów tworzy w nich kilkuletni podrost Pinus sylvestris. Warstwa zielna osiąga pokrycie 40-70\% (średnio 53\%) i przeważnie bywa luźniejsza od warstwy mszystej. Jej najważniejszym pod względem diagnostycznym i fizjonomicznym elementem jest rosnąca zwykle w równomiernym rozproszeniu, osiągająca $30 \mathrm{~cm}$ wysokości i tworząca charakterystyczne rozety liściowe Androsace septentrionalis (ryc. 3). Obecność tego gatunku pozwala na łatwą identyfikację płatów zespołu przez znaczną część okresu wegetacyjnego, także po okresie masowego pojawu terofitów wczesnowiosennych. W wielu fitocenozach licznie rosną też m.in.: Artemisia campestris s.s., Centaurea stoebe, Cerastium semidecandrum, Hieracium pilosella, Medicago minima i Trifolium arvense. Warstwa mszysta pokrywa 30-85\%

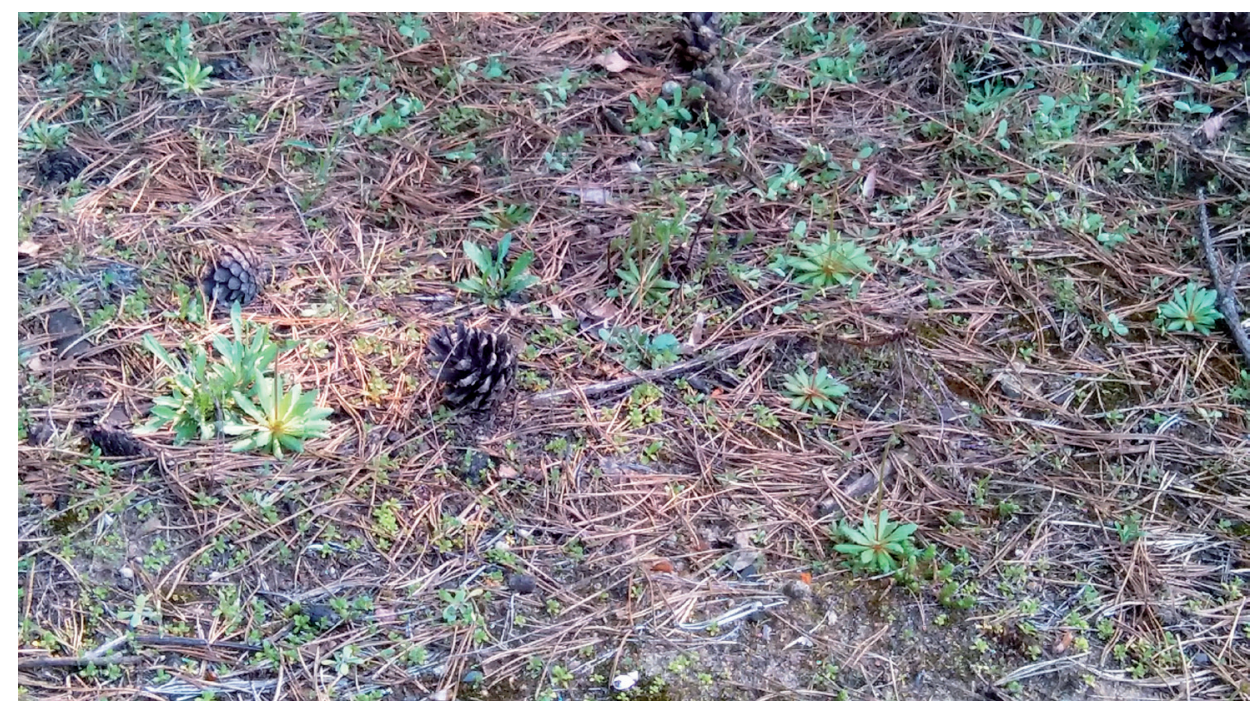

Ryc. 3. Fragment fitocenozy zespołu Cerastio semidecandri-Androsacetum septentrionalis w pobliżu budynków Wydziału Nauk Geograficznych i Geologicznych.

Fot. T. Szygendowski, 17.04.2017 r.

Fig. 3. Fragment of a phytocoenosis of the Cerastio semidecandri-Androsacetum septentrionalis near the buildings of the Faculty of Geographical and Geological Sciences.

Phot. T. Szygendowski, 17.04.2017 
(średnio 65\%) powierzchni gleby. Najobficiej występują w niej Brachythecium albicans i Ceratodon purpureus, tworzące zwarte skupiska, a w wielu płatach pojawiają się porosty.

Płaty tego zespołu na badanym terenie są stosunkowo bogate florystycznie (25-37, średnio 31 taksonów w zdjęciu). Trzon florystyczny asocjacji tworzą gatunki diagnostyczne związku i klasy Koelerio-Corynephoretea, ważną grupę stanowią też gatunki muraw kserotermicznych z klasy Festuco-Brometea, podczas gdy mało licznie i zwykle z obniżoną żywotnością pojawiają się rośliny synantropijne z klas Artemisietea vulgaris i Stellarietea mediae.

Zróżnicowanie. $\mathrm{Z}$ analizy wszystkich dostępnych materiałów, dotyczących omawianego zespołu na terenie Wielkopolski, wynika, że może on się realizować w postaci dwóch dość różnych, niepodawanych dotychczas w literaturze, podzespołów. Na kampusie UAM spotyka się wyłącznie płaty podzespołu typowego, wyróżniającego się przede wszystkim negatywnie w stosunku do następnego.

\section{Subass. C.s.-A.s. typicum Brzeg et Szygendowski 2017 subass. nova hoc loco}

Typ nomenklatoryczny: tab. 1, zdj. 2 (oryg.) holotypus hoc loco

D. Subass. (reg.): Festuca rubra, Medicago minima, Petrorhagia prolifera, Plantago arenaria (tab. 6, kol. 1).

W obrębie aglomeracji Poznania, a także we wschodniej Wielkopolsce, na obszarach piaszczystych w kontakcie przestrzennym z murawami związków Koelerion glaucae i Phleion boehmeri, występują, nieobecne w granicach kampusu UAM, fitocenozy podzespołu macierzankowego, którego formalną diagnozę przedstawiono poniżej.

\section{Subass. C.s.-A.s. thymetosum serpylli Brzeg et Szygendowski 2017 subass. nova hoc loco}

Typ nomenklatoryczny: zdj. 33/KZ, 31.05.1997, Kowalewek, gm. Rzgów, pow. Konin, przekształcone piaszczyska między borem sosnowym a autostradą A2, S, 8, c 60\%, d 75\%, $10 \mathrm{~m}^{2}$, 29 taksonów: Ch., D. Ass.: Andosace septentrionalis 1.2, Pinus sylvestris + , Calamgrostis epigejos $+^{+}$; D. Subass.: Thymus serpyllum 1.2, Niphotrichum canescens 1.2, Festuca psammophila +.2 , Koeleria glauca +.2, Cetraria aculeata +, Cladonia glauca +; Ch., D. All.: Cerastium semidecandrum 2.4, Erophila verna 1.1, Senecio vernalis 1.1, Arabidopsis thaliana + , Arenaria serpyllifolia +; Ch. O. et Cl.: Ceratodon purpureus 4.4, Helichrysum arenarium 2.2, Polytrichum piliferum 2.2, Corynephorus canescens 1.2, Cladonia furcata var. palamaea 1.2, Cladonia subulata 1.1, Rumex tenuifolius 1.1, Trifolium arvense 1.1, Brachythecium albicans +.2 , Sedum acre +.2 , Agrostis vinealis +, Jasione montana +; Inne (others): Artemisia campestris s.s. +, Conyza canadensis +, Linaria vulgaris $+^{\circ}$ (autor A. Brzeg) holotypus hoc loco

D. Subass. (reg.): Carex praecox, Cephaloziella divaricata, Cetraria aculeata, Cladonia chlorophaea, Cladonia glauca, Festuca psammophila, Galium verum s.s., Koeleria glauca, Niphotrichum canescens, Potentilla arenaria, Silene chlorantha, Thymus serpyllum (tab. 6, kol. 2).

Rozmieszczenie i lokalne warunki występowania. Z dotychczasowych danych wynika, że Cerastio semidecandri-Androsacetum septentrionalis jest 
w Wielkopolsce i na terenach przyległych zbiorowiskiem rzadkim (Głowacki 1984; Brzeg, Janyszek 1998; Brzeg, Wojterska 2001). W granicach kampusu UAM jego płaty znaleziono wyłącznie na obrzeżach zadrzewień sosnowych, położonych u zbiegu ulic B. Krygowskiego i Zagajnikowej, na północ od budynków Wydziału Nauk Geograficznych i Geologicznych. Porastały tam szkieletowe gleby piaszczyste o charakterze inicjalnym, wcześniej przekształcone w wyniku prac ziemnych. Interesujący wydaje się fakt, że znaczna część tych płatów jest dość trwała; pojawiają się one przez wiele lat w tych samych miejscach mimo zacieniania przez coraz wyższe osobniki sosny.

Tabela 1 - Table 1

Cerastio semidecandri-Androsacetum septentrionalis Głowacki 1988 ex Brzeg et M. Wojterska 2001

\begin{tabular}{|c|c|c|c|c|c|c|c|c|c|}
\hline Numer kolejny - Successive No. & 1 & 2 & 3 & 4 & 5 & 6 & 7 & 8 & \multirow{12}{*}{ 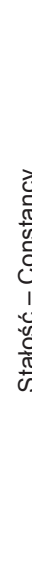 } \\
\hline dzień (day) & 24 & 20 & 24 & 24 & 30 & 27 & 23 & 24 & \\
\hline miesiąc (month) & 04 & 04 & 05 & 5 & 05 & 04 & 05 & 04 & \\
\hline rok (year) 20.. & 15 & 15 & 15 & 15 & 16 & 16 & 15 & 15 & \\
\hline Wystawa - Slope exposure & - & $\mathrm{S}$ & SE & SW & - & - & - & $S$ & \\
\hline Nachylenie - Inclination [ $\left.{ }^{\circ}\right]$ & - & 2 & 2 & 2 & - & - & - & 5 & \\
\hline Zwarcie warstwy krzewów b \% & + & + & + & $t$ & $t$ & - & 5 & 5 & \\
\hline Density of shrub layer & + & & 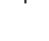 & $T$ & r & 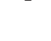 & $\checkmark$ & $\mathrm{J}$ & \\
\hline $\begin{array}{l}\text { Pokrycie warstwy zielnej c \% } \\
\text { Cover of herb layer }\end{array}$ & 70 & 50 & 60 & 50 & 50 & 40 & 65 & 40 & \\
\hline $\begin{array}{l}\text { Pokrycie warstwy mszystej d \% } \\
\text { Cover of moss layer }\end{array}$ & 75 & 85 & 80 & 80 & 60 & 30 & 70 & 40 & \\
\hline Powierzchnia zdjęcia - Area of relevé [ $\left.\mathrm{m}^{2}\right]$ & 6 & 12 & 7 & 15 & 8 & 3 & 15 & 5 & \\
\hline Liczba taksonów - Number of taxa & 26 & 30 & 29 & 37 & 33 & 34 & 32 & 25 & \\
\hline \multicolumn{10}{|l|}{ I. Ch., *D. Ass. } \\
\hline Androsace septentrionalis & 1.1 & 2.1 & 1.1 & 1.1 & 3.1 & 2.2 & 2.1 & 2.3 & $\mathrm{~V}$ \\
\hline${ }^{*}$ Pinus sylvestris b/c & + & + & + & + & 1.2 & . & 1.2 & 1.2 & V \\
\hline${ }^{*}$ Calamagrostis epigejos & . & $++^{\circ}$ & $++^{\circ}$ & 1.1 & . & . & . & $+{ }^{\circ}$ & III \\
\hline \multicolumn{10}{|l|}{$\begin{array}{l}\text { Il. Ch., *D. Sileno conicae-Cerastion } \\
\text { semidecandri }\end{array}$} \\
\hline Cerastium semidecandrum & 4.4 & 3.1 & 2.1 & 2.1 & 2.1 & 2.3 & 2.1 & + & V \\
\hline Erophila verna fo. & + & 1.2 & 1.2 & 2.2 & + & 1.1 & 1.1 & + & V \\
\hline Arenaria serpyllifolia & +.2 & . & $++^{\circ}$ & + & 1.1 & + & . & . & IV \\
\hline Holosteum umbellatum & 1.1 & + & . & . & . & 1.1 & 1.2 & . & III \\
\hline${ }^{\star}$ Bromus tectorum & . & $+\circ$ & $+\circ$ & + & r & . & . & . & III \\
\hline Myosotis stricta & + & + & . & 1.1 & . & + & . & . & III \\
\hline${ }^{*}$ Arabidopsis thaliana & 1.1 & . & . & $r$ & . & . & . & + & II \\
\hline Senecio vernalis & + & . & . & $\mathrm{r}^{\circ}$ & . & + & . & . & II \\
\hline Cerastium glutinosum & . & . & . & +.2 & + & . & . & . & II \\
\hline
\end{tabular}


III. Ch. Koelerio-Corynephoretea

Brachythecium albicans

Ceratodon purpureus

Trifolium arvense

Vicia lathyroides

Corynephorus canescens

Sedum acre

Rumex tenuifolius

Veronica dillenii

Jasione montana

Helichrysum arenarium

Rumex acetosella s.s.

Cladonia subulata s.l.

Polytrichum piliferum

Chondrilla juncea

Cladonia furcata var. palamaea

Scleranthus perennis

Peltigera didactyla

\section{Ch. Festuco-Brometea}

Artemisia campestris s.s.

Centaurea stoebe

Syntrichia ruralis

Achillea pannonica

Festuca trachyphylla

Medicago minima

Poa compressa

Petrorhagia prolifera

\section{Ch. Artemisietea vulgaris}

Oenothera biennis

Berteroa incana

Echium vulgare

\section{Inne (Others)}

Vicia hirsuta

Hieracium pilosella

Festuca rubra

Cladonia fimbriata

Rumex acetosa

Bryum caespiticium

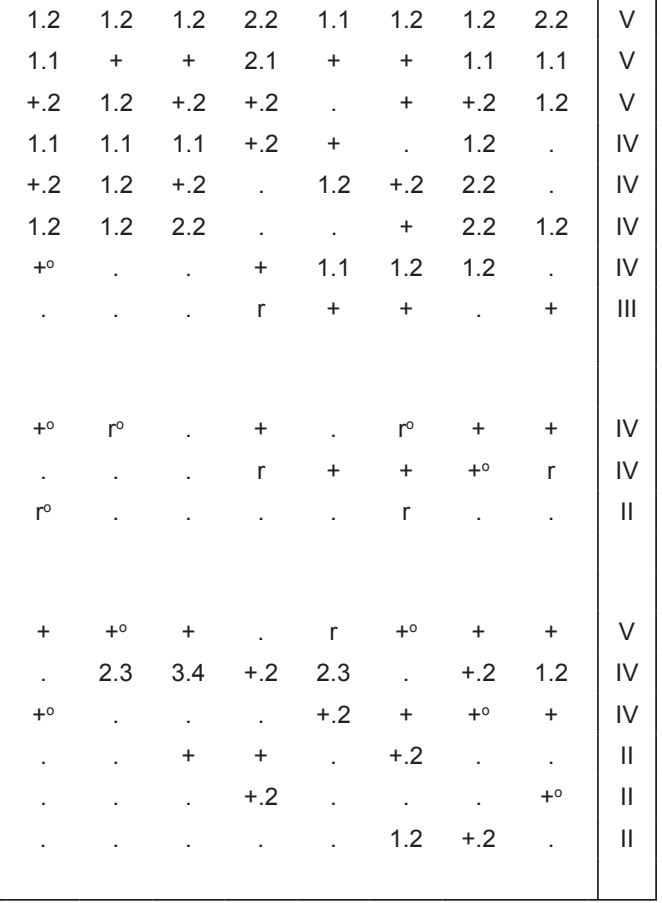

Taksony sporadyczne z tabeli 1 (Sporadic taxa from Table 1): III: Cladonia cervicornis ssp. verticillata 4(+); Festuca ovina 3(+); Potentilla argentea 6(+); IV: Euphorbia cyparissias 7(+); Poa angustifolia var. collina 4(+); V: Artemisia vulgaris 5(+); Medicago lupulina 7(+); Oenothera rubricaulis 7(1.1); VI: Bryum argenteum 6(+); Carex hirta 7(r); Cladonia coniocraea 6(+); Conyza canadensis 4(r); Populus nigra b/c 7(1.2); Quercus robur c $5(r)$; Setaria viridis $6(+)$; Veronica arvensis 2(r); Vicia villosa $8(r)$; Viola arvensis $5(r)$. 


\section{Myosotido strictae-Arabidopsietum thalianae \\ (tab. 2; tab. 6, kol. 3)}

D. Ass. (reg.): Arabidopsis thaliana, Erophila verna (opt.), Holosteum umbellatum (opt.) i lok. inne Ch., D. All. (zespół centralny związku)

Struktura i skład florystyczny. W odróżnieniu od Cerastio semidecandri-Androsacetum septentrionalis płaty zespołu niezapominajki piaskowej i rzodkiewnika pospolitego mają charakter krótkotrwały i dobrze widoczne oraz łatwo rozpoznawalne są tylko podczas wiosennego aspektu z panującymi terofitami (od kwietnia do połowy czerwca). Niska warstwa zielna zwykle wyraźnie przeważa nad mszystą (ryc. 4), pokrywając $60-85 \%$ (średnio $71 \%$ ) powierzchni gleby. O jej fizjonomii decydują przede wszystkim współpanujące drobne, biało kwitnące gatunki związku: Arabidopsis thaliana, Arenaria serpyllifolia, Cerastium semidecandrum, Erophila verna i Holosteum umbellatum, a także niebiesko kwitnąca Myosotis stricta. Ważną rolę odgrywają też m.in.: Artemisia campestris s.s., Helichrysum arenarium, Hieracium pilosella, Lolium perenne, Trifolium arvense i Veronica arvensis (por. Passarge 1996). Ilościowa rola bylin, w tym traw, w kolejnych miesiącach stopniowo wzrasta kosztem obumierających

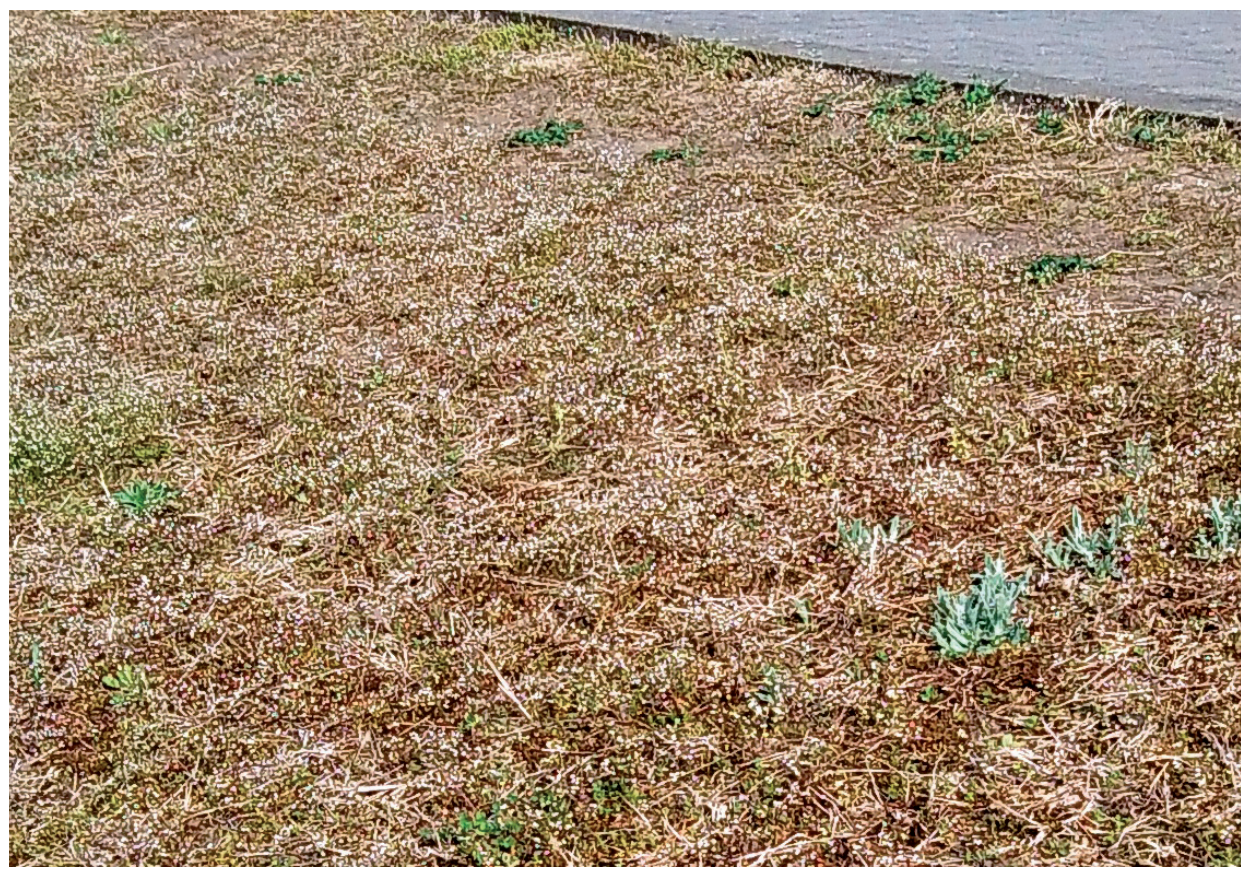

Ryc. 4. Płat zespołu Myosotido strictae-Arabidopsietum thalianae na tyłach budynków

Wydziału Fizyki. Fot. T. Szygendowski, 17.04.2017 r.

Fig. 4. Patch of the Myosotido strictae-Arabidopsietum thalianae behind the buildings of the Faculty of Physics. Phot. T. Szygendowski, 17.04.2017 
terofitów. Pokrycie warstwy mszystej waha się od 5\% do 75\% w niektórych postaciach zespołu (średnio osiąga 36\%). Jej najważniejszymi składnikami są Brachythecium albicans i Ceratodon purpureus. Rzadziej większą ilościowość osiągają Polytrichum piliferum i Syntrichia ruralis.

Fitocenozy asocjacji lokalnie charakteryzują się stosunkowo dużym bogactwem i urozmaiceniem florystycznym (28-38, średnio 33 taksony w zdjęciu), odbiegając pod tym względem nieco od średniej dla regionu Wielkopolski (por. tab. 6). Zrąb florystyczny omawianego syntaksonu tworzą przede wszystkim gatunki diagnostyczne związku i klasy Koelerio-Corynephoretea, istotną domieszkę, przynajmniej w wielu płatach, stanowią taksony przechodzące ze zbiorowisk klas: Artemisietea vulgaris, Stellarietea mediae, Molinio-Arrhenatheretea, a nawet Polygono-Poetea annuae, podczas gdy znacząco słabszą niż w poprzednim zespole grupę stanowią kserotermy z klasy Festuco-Brometea.

Zróżnicowanie. $\mathrm{Z}$ uwagi na brak obfitszych materiałów porównawczych $\mathrm{z}$ innych terenów trudno wypowiedzieć się o powtarzalnej zmienności opisywanego zespołu w regionie. Na podstawie zdjęć z obszaru kampusu UAM wyróżnić można $\mathrm{w}$ jego ramach dwie dość wybitne postacie: z Lolium perenne (zdj. 1-5) i z Corynephorus canescens (zdj. 6-8). Fitocenozy pierwszej postaci realizują się zdecydowanie częściej i na większych powierzchniach, w obrębie rozległych trawników kampusu, a drugiej - w sąsiedztwie muraw szczotlichowych związku Corynephorion canescentis. Prawdopodobnie w przyszłości zmienność zespołu można będzie ująć w ramach osobnych podzespołów. Odnosząc się do ujęcia Passarge (1996), należy zauważyć, że zdecydowana większość płatów z Wielkopolski bliższa jest wyróżnionemu przez tego autora podzespołowi M.s.-A.t. veronicetosum nom. inval. (Art. $3 \mathrm{~g}$ ICPN), ale nie jest $\mathrm{z}$ nim tożsama.

Rozmieszczenie i lokalne warunki występowania. W dotychczasowej literaturze fitosocjologicznej z Wielkopolski znaleziono jedynie pojedyncze zdjęcia reprezentujące interesujący nas typ roślinności, interpretowane w ramach innych jednostek. $Z$ badań przeprowadzonych na kampusie UAM, gdzie występuje praktycznie w otoczeniu zabudowań wszystkich wydziałów oraz wzdłuż dróg i ścieżek, a także z obserwacji na innych terenach wynika, że jest to zbiorowisko pospolite zarówno na obszarach miejskich, jak i wiejskich (Wojterska $i$ in. 2016). Pojawia się ono na niedawno antropogenicznie przeobrażonych podłożach piaszczystych (miejsca erodowane, wydeptywane, przekopywane, grunty porolne itp.), a także jako synuzje w obrębie innego typu muraw i suchszych łąk w miejscach erodowanych przez dziką zwierzynę, zwłaszcza dziki. Omawiane zbiorowisko ma charakter pionierski i po kilku sezonach wegetacyjnych, w przypadku braku ingerencji w podłoże, ustępuje miejsca ugrupowaniom bardziej trwałym. 
Tabela 2 - Table 2

Myosotido strictae-Arabidopsietum thalianae Pass. (1962) 1977

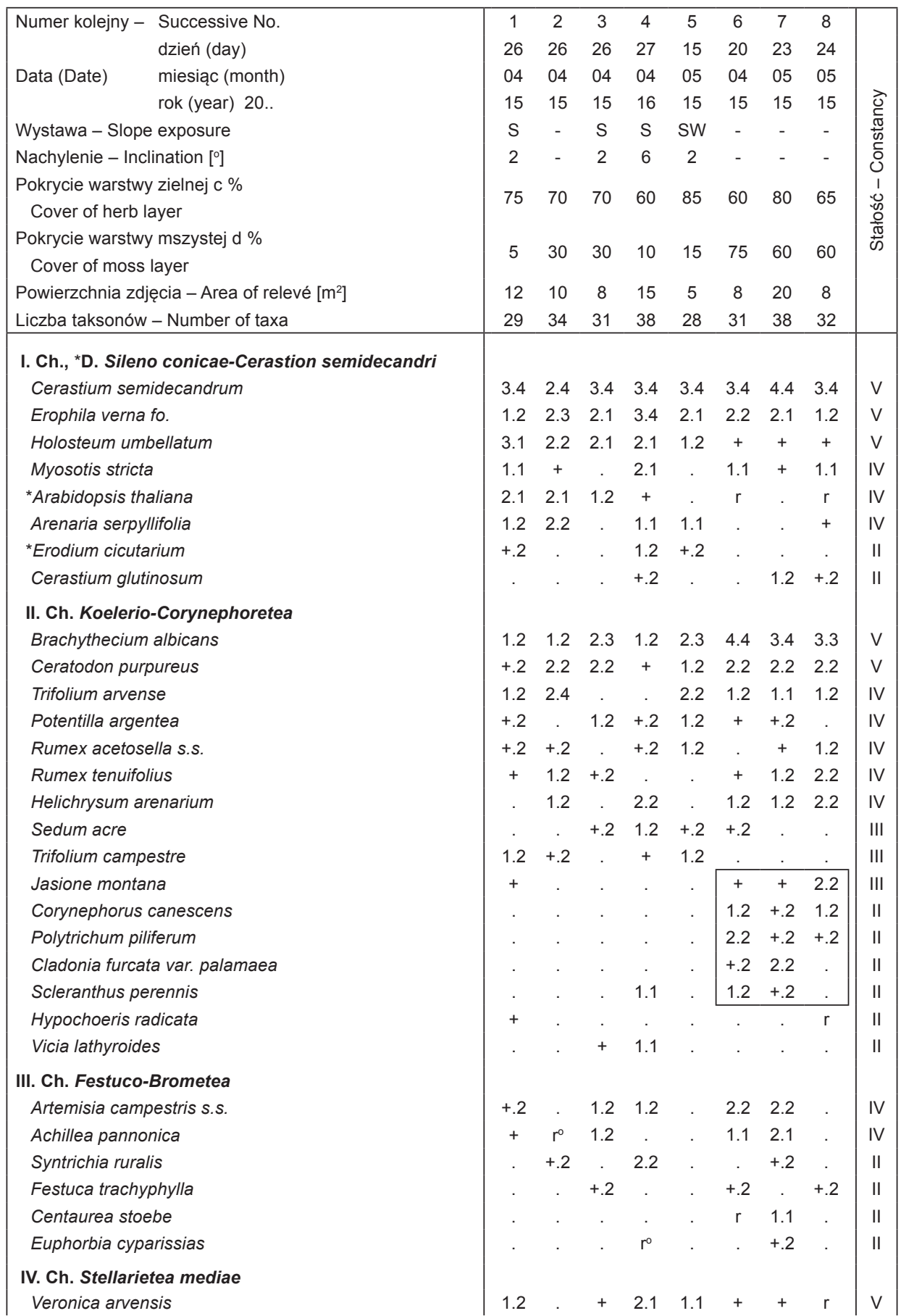




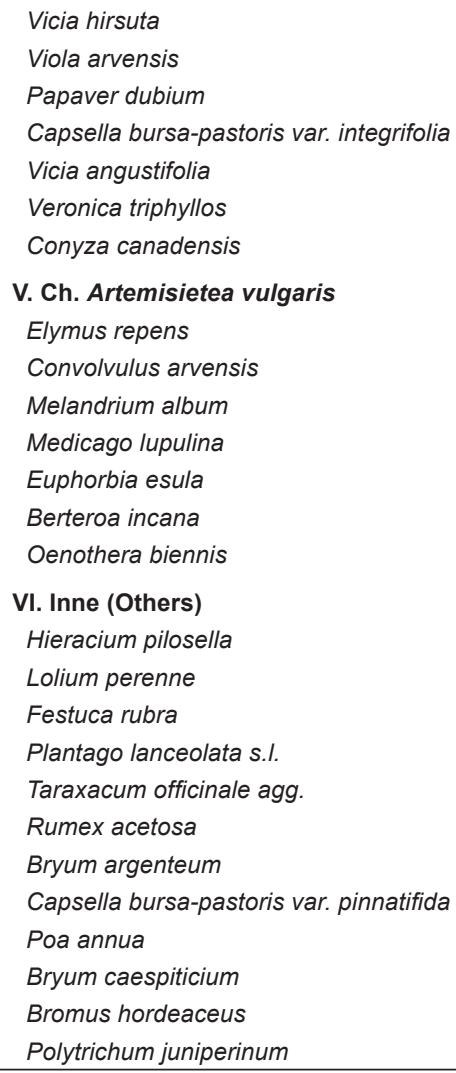

\section{Ch. Artemisietea vulgaris}

Elymus repens

Convolvulus arvensis

Melandrium album

Medicago Iupulina

Euphorbia esula

Berteroa incana

Oenothera biennis

\section{Inne (Others)}

Hieracium pilosella

Lolium perenne

Festuca rubra

Plantago lanceolata s.I.

Taraxacum officinale agg.

Rumex acetosa

Bryum argenteum

Capsella bursa-pastoris var. pinnatifida

Poa annua

Bryum caespiticium

Bromus hordeaceus

Polytrichum juniperinum

\begin{tabular}{|c|c|c|c|c|c|c|c|c|}
\hline . & $r^{0}$ & . & . & . & + & +0 & +0 & III \\
\hline$r$ & . & . & . & . & . & . & + & II \\
\hline 1.1 & . & $r^{\circ}$ & + & . & . & . & . & II \\
\hline . & $r$ & +.2 & . & . & . & . & . & II \\
\hline . & . & $r$ & . & + & . & . & . & II \\
\hline . & $r$ & . & $r$ & . & . & . & . & II \\
\hline . & + & . & $r$ & . & . & . & . & II \\
\hline 1.2 & + & +0 & . & $+^{\circ}$ & $+\circ$ & $+^{\circ}$ & . & IV \\
\hline . & + & . & + & + & 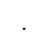 & . & +.2 & III \\
\hline . & $r$ & $r^{\circ}$ & . & + & . & . & . & II \\
\hline . & 1.2 & . & . & +.2 & . & . & . & II \\
\hline . & . & . & + & $r$ & . & . & . & II \\
\hline . & 1.1 & + & +.2 & . & . & . & . & II \\
\hline . & + & . & 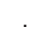 & . & $r^{\circ}$ & $r^{\circ}$ & . & II \\
\hline . & . & . & +.2 & +.2 & 2.1 & 2.2 & 1.2 & IV \\
\hline 1.2 & 1.2 & 1.2 & 1.2 & +.2 & . & . & . & IV \\
\hline . & +.2 & 1.2 & +.2 & +.2 & . & . & . & III \\
\hline . & +0 & +0 & +.2 & 2.1 & . & . & . & III \\
\hline . & $\mathrm{r}^{\circ}$ & $r$ & . & $\mathrm{r}^{0}$ & . & . & . & II \\
\hline+.2 & 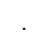 & +.2 & . & . & . & $+^{\circ}$ & . & II \\
\hline . & +.2 & . & + & . & . & . & . & II \\
\hline . & + & . & + & . & . & . & . & II \\
\hline . & +.2 & +.2 & . & . & . & . & . & II \\
\hline . & 1.2 & +.2 & . & . & . & . & +.2 & II \\
\hline . & . & + & . & . & . & + & $+^{\circ}$ & II \\
\hline . & . & . & . & . & . & 1.2 & 2.3 & II \\
\hline
\end{tabular}

Taksony sporadyczne z tabeli 2 (Sporadic taxa from Table 2): I: *Bromus tectorum 5(+); II: Cerastium arvense 3(+); Chondrilla juncea 7(r); Cladonia subulata s.I. 7(+); Placynthiella oligotropha 4(+); Teesdalea nudicaulis 8(+); Veronica verna 4(1.1); III: Poa angustifolia var. collina 5(1.2); Poa compressa 6(+); IV: Geranium pusillum 4(r); Papaver rhoeas 1(+); Scleranthus annuus 1(1.1); Senecio vulgaris 2(r); Setaria viridis 4(1.1); Sisymbrium altissimum 1(r); Veronica hederifolia 4(+); Vicia villosa 6(+); V: Daucus carota s.s. 3(+); Verbascum phlomoides 6(r); Verbascum thapsus 7(r); VI: Achillea millefolium 1(+); Anthoxanthum odoratum 8(+); Carex hirta 5(+); Cladonia fimbriata 8(+); Dicranum scoparium 7(+); Festuca arundinacea 5(+); Gagea pratensis 6(+); Hypericum perforatum 6(+); Hypnum cupressiforme var. lacunosum 7(+); Pinus sylvestris c 7(r); Rumex thyrsiflorus 7(+); Secale cereale 8(r); Senecio jacobaea 1(+); Solidago virgaurea 8(1.2).

\section{Arenario-Sedetum acris (tab. 3; tab. 6, kol. 4)}

Ch. Ass. (reg.): Sedum acre (dom.); D. Ass. (reg.): Achillea collina, Medicago lupulina, Trifolium dubium

Struktura i skład florystyczny. Do zespołu piaskowca macierzankowego i rozchodnika ostrego należą ugrupowania niskich, zwartych muraw, wykazujące zawsze strukturę dwuwarstwową. Od pozostałych zbiorowisk związku Sileno conicae-Cerastion semidecandri fitocenozy tej asocjacji odróżnia dominacja sukulenta Sedum acre (ryc. 5) oraz, wyraźnie silniej zaznaczająca się w fizjonomii, składzie gatunkowym i stopniu pokrycia, rola kserotermicznych bylin. Warstwę ziół, pokrywającą 70-80\% powierzchni płatów (przeciętnie 76\%), współtworzą, 


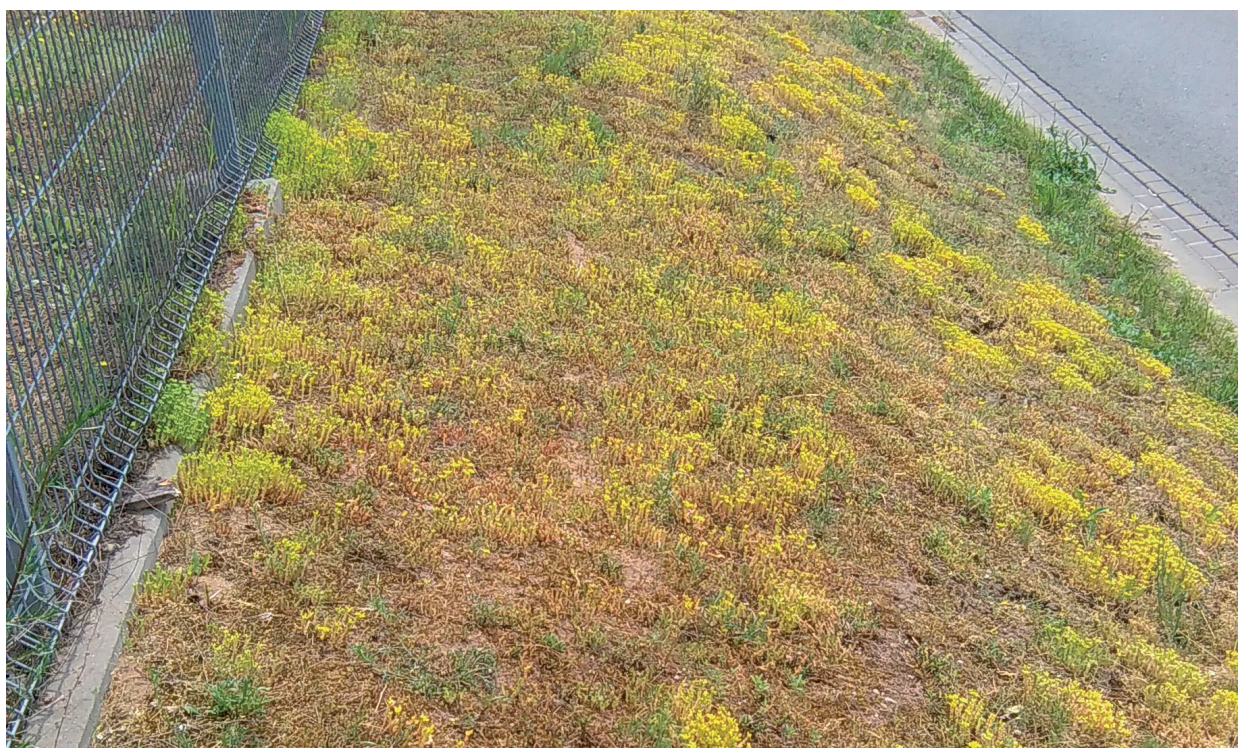

Ryc. 5. Płat zespołu Arenario-Sedetum acris porastający skarpę wzdłuż ulicy B. Krygowskiego w pobliżu budynków Wydziału Nauk Geograficznych i Geologicznych. Fot. T. Szygendowski, 30.05.2016 r.

Fig. 5. Patch of the Arenario-Sedetum acris overgrowing an escarpment along B. Krygowski street near the buildings of the Faculty of Geographical and Geological Sciences.

Phot. T. Szygendowski, 30.05.2016

obok dominanta, rośliny wieloletnie, jak m.in: Achillea pannonica, Artemisia campestris s.s., Festuca rubra, Helichrysum arenarium, Hieracium pilosella, oraz liczne terofity: Arenaria serpyllifolia, Cerastium semidecandrum, Holosteum umbellatum, Trifolium arvense, T. campestre i inne. Pokrycie warstwy mszystej bywa zróżnicowane (15-80\%, średnio 44\%). Jej głównymi komponentami są Brachythecium albicans i Ceratodon purpureus, którym często towarzyszą Bryum caespiticium i Syntrichia ruralis.

$\mathrm{Na}$ tle fitocenoz udokumentowanych z innych obszarów Wielkopolski (por. tab. 6), płaty zespołu spotykane na terenie kampusu UAM odznaczają się dużym bogactwem florystycznym; w zdjęciach stwierdzano 29-34, przeciętnie 31 taksonów (średnia w regionie 27). W składzie asocjacji znaczący udział mają gatunki charakterystyczne związku i klasy Koelerio-Corynephoretea, a w niektórych płatach także przechodzące z kserotermicznych muraw klasy Festuco-Brometea bądź z użytków zielonych klasy Molinio-Arrhenatheretea. Taksony diagnostyczne dla zbiorowisk synantropijnych są mniej licznie reprezentowane i przeważnie wykazują obniżoną żywotność.

Zróżnicowanie. Podobnie jak w przypadku poprzednio omówionej asocjacji, zgromadzony materiał fitosocjologiczny, dotyczący zespołu Arenario-Sedetum 
Tabela 3 - Table 3

Arenario-Sedetum acris (Hallberg 1971) Pass. 1977

\begin{tabular}{|c|c|c|c|c|c|c|c|c|c|c|c|}
\hline \multirow[t]{2}{*}{ Numer kolejny } & Successive No. & 1 & 2 & 3 & 4 & 5 & 6 & 7 & 8 & 9 & \\
\hline & dzień (day) & 24 & 01 & 26 & 23 & 24 & 06 & 14 & 14 & 29 & \\
\hline \multirow[t]{2}{*}{ Data (Date) } & miesiąc (month) & 04 & 06 & 04 & 05 & 05 & 05 & 05 & 05 & 04 & \\
\hline & rok (year) 20.. & 15 & 16 & 15 & 15 & 15 & 15 & 15 & 15 & 15 & \\
\hline \multicolumn{2}{|c|}{ Wystawa - Slope exposure } & - & - & - & W & - & S & - & - & SE & ত্ \\
\hline \multicolumn{2}{|c|}{ Nachylenie - Inclination [ $\left.{ }^{\circ}\right]$} & - & - & - & 20 & - & 3 & - & - & 2 & $\frac{\pi}{\omega}$ \\
\hline \multicolumn{2}{|c|}{ Zwarcie warstwy krzewów b \% } & + & - & - & - & - & - & - & - & - & ర్ \\
\hline \multicolumn{2}{|c|}{ Density of shrub layer } & & & & & & 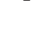 & 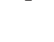 & & 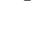 & .1 \\
\hline \multicolumn{2}{|c|}{ Pokrycie warstwy zielnej c \% } & 70 & 75 & 80 & 75 & 75 & 75 & 80 & 80 & 70 & $\begin{array}{l}\frac{\pi}{0} \\
\frac{0}{\pi} \\
\text { के }\end{array}$ \\
\hline \multicolumn{2}{|c|}{ Cover of moss layer } & 80 & 35 & 45 & 80 & 65 & 20 & 15 & 40 & 20 & \\
\hline \multicolumn{2}{|c|}{ Powierzchnia zdjęcia - Area of relevé $\left[\mathrm{m}^{2}\right]$} & 8 & 10 & 12 & 15 & 15 & 10 & 6 & 12 & 6 & \\
\hline \multicolumn{2}{|c|}{ Liczba taksonów - Number of taxa } & 30 & 34 & 29 & 35 & 33 & 30 & 31 & 32 & 29 & \\
\hline \multicolumn{12}{|c|}{ I. Ch., *D. Ass. } \\
\hline \multicolumn{2}{|l|}{ Sedum acre } & 3.4 & 4.4 & 4.4 & 4.4 & 3.4 & 4.4 & 4.4 & 4.4 & 4.4 & V \\
\hline \multicolumn{2}{|c|}{${ }^{*}$ Medicago Iupulina } & +.2 & 1.1 & . & + & . & +.2 & 1.2 & 1.2 & +.2 & IV \\
\hline \multicolumn{2}{|c|}{ *Achillea collina } & . & +.2 & . & . & . & + & $++^{\circ}$ & . & + & III \\
\hline \multicolumn{2}{|c|}{${ }^{*}$ Trifolium dubium } & . & . & . & . & . & . & +.2 & +.2 & . & II \\
\hline \multicolumn{12}{|c|}{ II. Ch., ${ }^{*}$ D. Sileno conicae-Cerastion semidecandri } \\
\hline \multicolumn{2}{|c|}{ Cerastium semidecandrum } & 2.2 & 2.3 & 2.3 & 2.4 & 2.4 & 2.3 & 3.3 & 3.4 & 1.2 & V \\
\hline \multicolumn{2}{|c|}{ Holosteum umbellatum } & 1.2 & 1.1 & + & + & + & 2.1 & + & 1.1 & 2.1 & $\mathrm{~V}$ \\
\hline \multicolumn{2}{|c|}{ Arenaria serpyllifolia } & . & 1.1 & 1.2 & 2.1 & + & 1.1 & 2.2 & 1.2 & 1.2 & V \\
\hline \multicolumn{2}{|c|}{ Erophila verna fo. } & . & + & + & 1.1 & 2.1 & 1.1 & 1.1 & 1.1 & 2.2 & V \\
\hline \multicolumn{2}{|c|}{${ }^{*}$ Arabidopsis thaliana } & $r$ & + & + & . & . & . & . & 1.1 & . & III \\
\hline \multicolumn{2}{|c|}{${ }^{*}$ Erodium cicutarium } & . & + & . & . & +.2 & . & . & +.2 & $\mathrm{r}^{\circ}$ & III \\
\hline Myosotis stric & & . & . & . & . & 2.1 & + & . & + & + & III \\
\hline${ }^{*}$ Bromus tecto & & . & . & . & + & . & 1.2 & . & . & $r$ & II \\
\hline Senecio vern & & . & . & . & $r^{\circ}$ & . & $++^{\circ}$ & . & . & . & II \\
\hline III. Ch. Koeler & o-Corynephoretea & & & & & & & & & & \\
\hline Brachytheciur & albicans & 2.2 & 3.4 & 3.4 & 4.4 & 4.4 & 2.3 & +.2 & 3.4 & 2.3 & V \\
\hline Ceratodon pu & bureus & 4.4 & 1.2 & 1.2 & 1.2 & 2.2 & 1.2 & 2.2 & +.2 & 1.2 & V \\
\hline Trifolium arve & & 2.2 & 1.1 & 1.2 & 1.2 & 1.2 & + & 1.2 & 1.1 & 1.2 & V \\
\hline Helichrysum & enarium & 1.2 & +.2 & +.2 & . & 2.2 & 1.2 & . & +.2 & +.2 & IV \\
\hline Trifolium cam & estre & +.2 & 1.2 & +.2 & 1.2 & . & +.2 & +.2 & 1.2 & . & IV \\
\hline Rumex tenuif & lius & + & + & $r$ & . & 2.2 & . & . & 1.2 & +.2 & IV \\
\hline Vicia lathyroic & & $r$ & + & . & . & + & . & . & 1.1 & . & III \\
\hline Potentilla arg & ntea & . & . & . & . & + & +.2 & +.2 & 1.2 & . & III \\
\hline Rumex aceto & ella s.s. & . & . & . & + & +.2 & 1.2 & +.2 & . & . & III \\
\hline Jasione mont & & + & . & . & + & 1.2 & . & . & . & . & II \\
\hline
\end{tabular}


Veronica dillenii

Hypochoeris radicata

Cladonia subulata s.l.

Scleranthus perennis

IV. Ch. Festuco-Brometea

Artemisia campestris s.s.

Achillea pannonica

Festuca trachyphylla

Syntrichia ruralis

Medicago minima

Centaurea stoebe

Euphorbia cyparissias

Poa angustifolia var. collina

V. Ch. Stellarietea mediae

Veronica arvensis

Conyza canadensis

Papaver dubium

Vicia hirsuta

\section{Ch. Artemisietea vulgaris}

Elymus repens

Oenothera biennis

Berteroa incana

Melandrium album

Daucus carota s.s.

\section{Inne (Others)}

Hieracium pilosella

Festuca rubra

Plantago lanceolata s.I.

Lolium perenne

Bryum caespiticium

Festuca arundinacea

Rumex acetosa

\begin{tabular}{|c|c|c|c|c|c|c|c|c|c|}
\hline . & . & . & . & + & . & . & . & + & II \\
\hline . & . & $r$ & . & . & . & $r$ & +.2 & . & II \\
\hline . & . & +.2 & . & . & +.2 & . & . & . & II \\
\hline . & . & 2.2 & . & . & . & . & . & +.2 & II \\
\hline 1.2 & +.2 & 1.2 & 1.2 & 1.2 & +.2 & +.2 & 1.2 & +.2 & V \\
\hline 1.1 & 1.2 & +.2 & . & 1.2 & . & +.2 & . & +.2 & IV \\
\hline 1.2 & +.2 & 2.2 & 1.2 & +.2 & . & . & . & . & III \\
\hline+.2 & +.2 & . & +.2 & +.2 & . & . & . & . & III \\
\hline 2.2 & + & 1.2 & . & . & . & . & . & . & II \\
\hline 1.1 & . & . & + & . & . & . & . & . & II \\
\hline$r$ & . & . & . & . & . & . & . & + & II \\
\hline . & . & + & . & . & . & . & . & +.2 & II \\
\hline . & + & . & + & 1.1 & + & 1.1 & 1.1 & . & IV \\
\hline . & . & . & 1.1 & $+^{\circ}$ & $r$ & + & . & . & III \\
\hline . & . & . & $r^{\circ}$ & + & . & . & $r$ & . & II \\
\hline$r$ & . & + & . & . & . & . & . & . & II \\
\hline . & $+^{\circ}$ & $+^{\circ}$ & . & $+^{\circ}$ & . & . & . & $+^{\circ}$ & III \\
\hline 1.1 & + & . & $r^{\circ}$ & . & . & . & . & . & II \\
\hline . & $r$ & . & $r$ & $r$ & . & . & . & . & II \\
\hline . & . & $r^{\circ}$ & . & $+^{\circ}$ & . & . & . & . & II \\
\hline . & . & . & $r^{\circ}$ & . & . & + & . & . & II \\
\hline . & +.2 & 1.3 & +.2 & +.2 & 1.3 & + & 2.2 & +.2 & V \\
\hline . & 2.2 & $+^{\circ}$ & . & $+{ }^{\circ}$ & 1.2 & 2.4 & +.2 & 1.2 & IV \\
\hline . & 2.2 & 1.1 & . & . & + & +.2 & $r$ & 1.1 & IV \\
\hline . & +.2 & +.2 & . & + & +.2 & +.2 & . & . & III \\
\hline . & . & +.2 & 2.2 & . & +.2 & +.2 & . & . & III \\
\hline . & $+^{\circ}$ & . & . & . & . & 1.2 & . & . & II \\
\hline . & . & . & $r^{\circ}$ & +.2 & . & . & . & . & II \\
\hline
\end{tabular}

Taksony sporadyczne z tabeli 3 (Sporadic taxa from Table 3): II: Androsace septentrionalis 1(r); III: Chondrilla juncea 3(+); Corynephorus canescens 1(+); Peltigera didactyla 4(+); Placynthiella oligotropha 6(1.2); Veronica verna 8(r); IV: Medicago falcata 4(+); Petrorhagia prolifera 4(r); Poa compressa 1(+); Verbascum lychnitis 5(r); V: Capsella bursa-pastoris var. integrifolia 7(r); Geranium pusillum 8(r); Lepidium densiflorum 7(+); Papaver argemone 4(r); Scleranthus annuus 9(r); Setaria viridis 7(r); Veronica triphyllos 8(+); Vicia angustifolia 2(+); Viola arvensis 4(r); VI: Cichorium intybus 2(r); Convolvulus arvensis 9(+); Echium vulgare 2(r); Melilotus officinalis 1(+); Oenothera rubricaulis 1(r); Picris hieracioides 1(r); Tragopogon dubius 1(r); Verbascum phlomoides 5(r); VII: Agrostis capillaris 6(+); Bromus hordeaceus 4(+); Capsella bursa-pastoris var. pinnatifida 4(r); Carex hirta 8(+); Dactylis glomerata 9(+); Pinus sylvestris b/c 1(+); Plantago major s.s. 7(r); Poa pratensis s.s. 8(+); Populus tremula juv. 8(r); Quercus robur c 2(r); Senecio jacobaea 8(r); Solidago virgaurea 6(+); Taraxacum officinale agg. $7(+)$; Trifolium pratense $6(+)$; Trifolium repens $9(+)$. 
acris, nie może być podstawą dyskusji nad jego zmiennością wewnętrzną. Mając na uwadze obserwowane w ostatnich latach dynamiczne rozprzestrzenianie się fitocenoz tego syntaksonu, zarówno na badanym terenie, jak i na obszarze zurbanizowanym całej aglomeracji Poznania, prawdopodobieństwo wykazania w jego obrębie niższych jednostek w toku dalszych badań wydaje się jednak wysokie (por. Passarge 1996; Ratyńska 2001; Wojterska 2003).

Rozmieszczenie i lokalne warunki występowania. Omawiany zespół, w przedstawionym ujęciu podany z Polski po raz pierwszy przez Ratyńską i in. (2010), stanowi, jak wspominano, pospolity na terenie kampusu UAM na Morasku składnik roślinności murawowej. Jego fitocenozy spotyka się na całym badanym obszarze, na podłożach piaszczystych i gliniasto-piaszczystych, nieraz szkieletowych, w miejscach o przekształconej w następstwie prac ziemnych pokrywie glebowej, gdzie tworzą mozaikę z innymi murawami interesującego nas związku, a także z płatami trawników zakładanych na uboższych i suchszych siedliskach. W procesie wtórnej sukcesji roślinności płaty Arenario-Sedetum acris stanowią stadium bardziej zaawansowane w stosunku do ugrupowań utworzonych w głównej mierze przez terofity wczesnowiosenne. Fakt ten przekłada się na zaobserwowane w latach 2016-2017 zjawisko znaczącego powiększania się areału fitocenoz charakteryzowanego syntaksonu kosztem muraw o bardziej pionierskim charakterze, reprezentujących m.in. Myosotido strictae-Arabidopsietum thalianae, a w szczególności zespół Erodio-Senecionetum vernalis.

\section{Erodio-Senecionetum vernalis (tab. 4; tab. 6, kol. 5)}

Ch. Ass. (reg.): Senecio vernalis (opt.); D. Ass. (reg.): Allium vineale, Erodium cicutarium (kodom.), Lamium purpureum, Sisymbrium loeselii, Veronica hederifolia

Struktura i skład florystyczny. Płaty zespołu iglicy pospolitej i starca wiosennego są dobrze widoczne oraz łatwo rozpoznawalne od wiosny do pełni lata. $\mathrm{Z}$ reguły mają strukturę dwuwarstwową. Warstwa zielna jest stosunkowo silnie rozwinięta (ryc. 6), osiągając pokrycie 70-90\% (średnio 76\%). Jej charakterystycznymi elementami, zwykle decydującymi o fizjonomii zbiorowiska, są z daleka widoczne, żółte koszyczki dorastającego do 30-40 cm wysokości Senecio vernalis oraz skupione przy powierzchni ziemi, fioletowo (czasami również biało) kwitnące kępki Erodium cicutarium. Towarzyszą im liczne gatunki diagnostyczne związku i klasy (m.in.: Arenaria serpyllifolia, Cerastium semidecandrum, Erophila verna, Helichrysum arenarium, Trifolium arvense i T. campestre). Wiele gatunków przechodzących z innych grup zbiorowisk podczas fenologicznego optimum zespołu występuje nielicznie, a nieco większe pokrywanie osiągają one dopiero w pełni lata (np. Achillea pannonica, Berteroa incana, Conyza canadensis, Echium vulgare). Pokrycie warstwy mszystej waha się w granicach 5-50\%, średnio osiąga 27\%. Jej skład gatunkowy jest bardzo podobny jak w innych zespołach związku na terenie badań. 


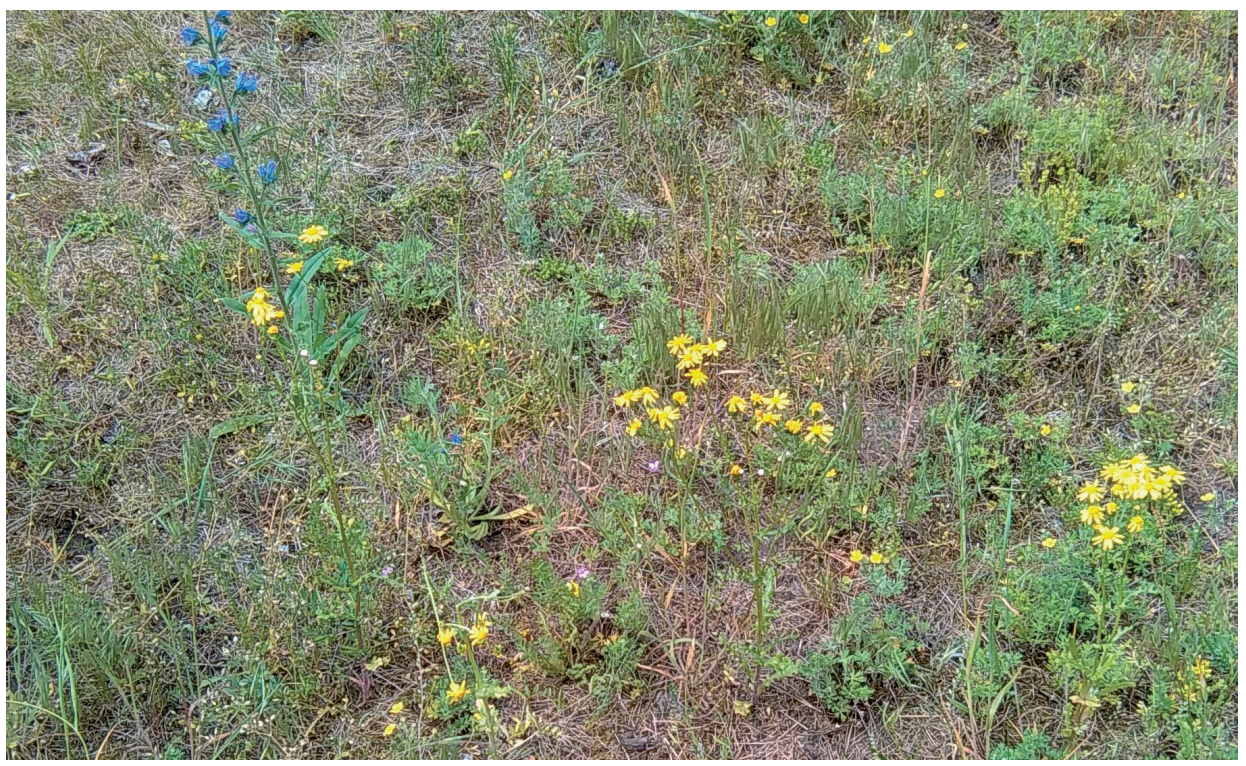

Ryc. 6. Fragment fitocenozy Erodio-Senecionetum vernalis w sąsiedztwie budynków Wydziału Fizyki. Fot. T. Szygendowski, 1.06.2017 r.

Fig. 6. Fragment of a phytocoenosis of the Erodio-Senecionetum vernalis in the vicinity of the buildings of the Faculty of Physics. Phot. T. Szygendowski, 1.06.2017

Wśród analizowanych muraw fitocenozy Erodio-Senecionetum vernalis charakteryzują się największym bogactwem florystycznym (w zdjęciach stwierdzano 33-43, przeciętnie 36 taksonów) i urozmaiceniem pod względem udziału gatunków z różnych grup syntaksonomicznych. Dotyczy to zarówno obszaru kampusu UAM, jak i całego regionu Wielkopolski (por. tab. 6). Oprócz gatunków związanych z różnego typu murawami: diagnostycznych związku i klasy Koelerio-Corynephoretea oraz charakterystycznych klasy Festuco-Brometea, w składzie asocjacji szczególnie licznie są reprezentowane taksony przechodzące z nitrofilnych ziołorośli klasy Artemisietea vulgaris i krótkotrwałych zbiorowisk klasy Stellarietea mediae, zarówno segetalnych, jak i ruderalnych.

Zróżnicowanie. Dotychczas zebrane dane fitosocjologiczne dokumentujące zespół w regionie są zbyt skąpe, by można było wyróżnić w jego obrębie podzespoły czy nawet wyraźniejsze postaci lokalne (por. Passarge 1996). Kwestia wewnętrznego zróżnicowania asocjacji wymaga dalszych badań; konieczne w tym celu będzie zgromadzenie obszerniejszego materiału z terenów, gdzie, w stosunku do obszaru kampusu UAM, jej fitocenozy są częstsze i występują nieraz na większych powierzchniach.

Rozmieszczenie i lokalne warunki występowania. Erodio-Senecionetum vernalis stanowi obecnie (rok 2017) na terenie kampusu UAM rzadko spotykany typ roślinności. W roku 2015 jego dość liczne płaty, z niemal kompletem gatunków 
Tabela 4 - Table 4

Erodio-Senecionetum vernalis Lührs 1993

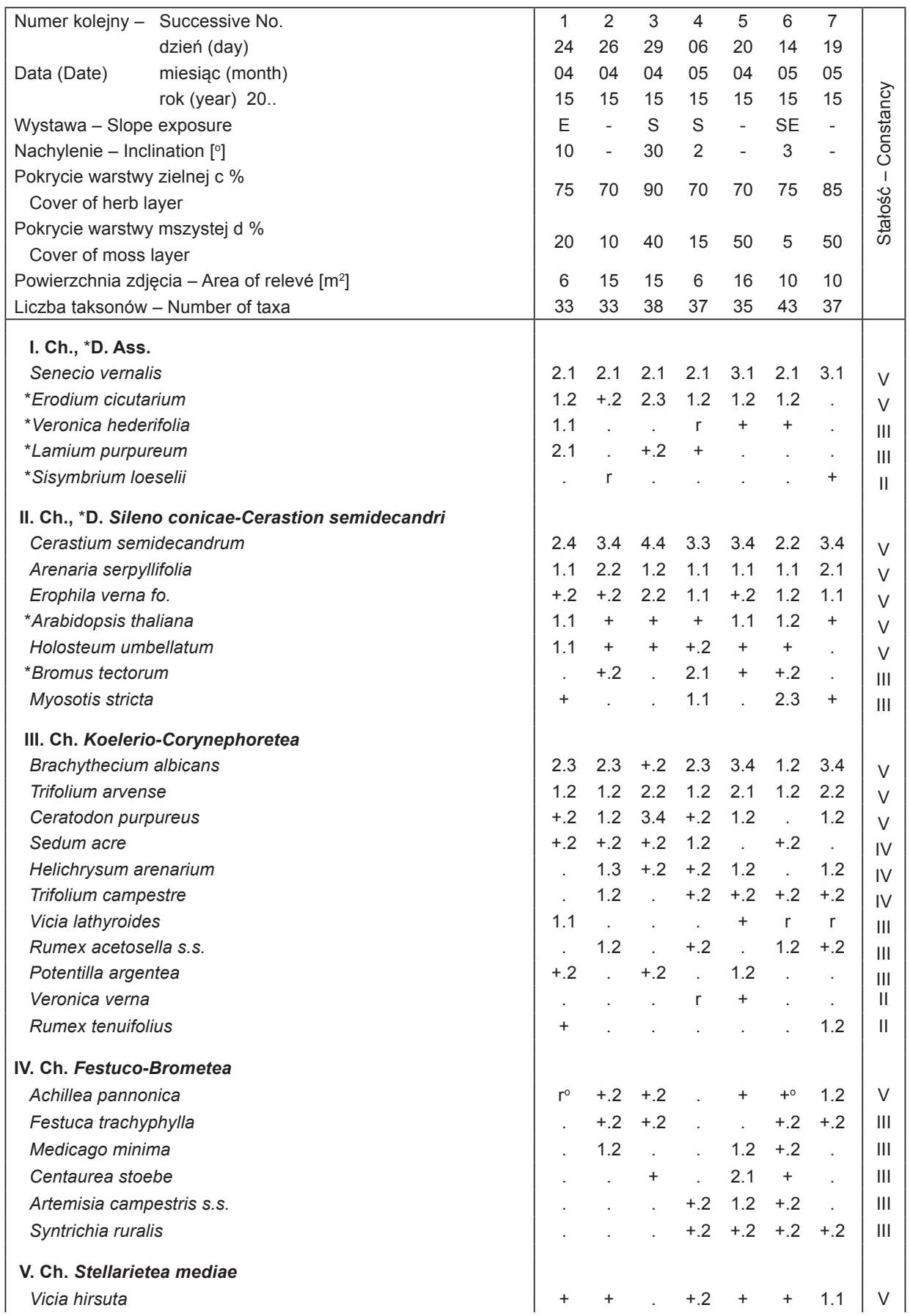




Conyza canadensis
Veronica arvensis
Anthemis arvensis
Capsella bursa-pastoris var.
Viola arvensis
Geranium pusillum
VI. Ch. Artemisietea vulgaris
Berteroa incana
Echium vulgare
Oenothera biennis
Elymus repens
Daucus carota s.s.
Euphorbia esula
Medicago lupulina
Linaria vulgaris
VII. Inne (Others)
Festuca rubra
Bryum caespiticium
Hieracium pilosella
Carex hirta
Senecio jacobaea
Lolium perenne
Bromus hordeaceus
Plantago lanceolata s.l.

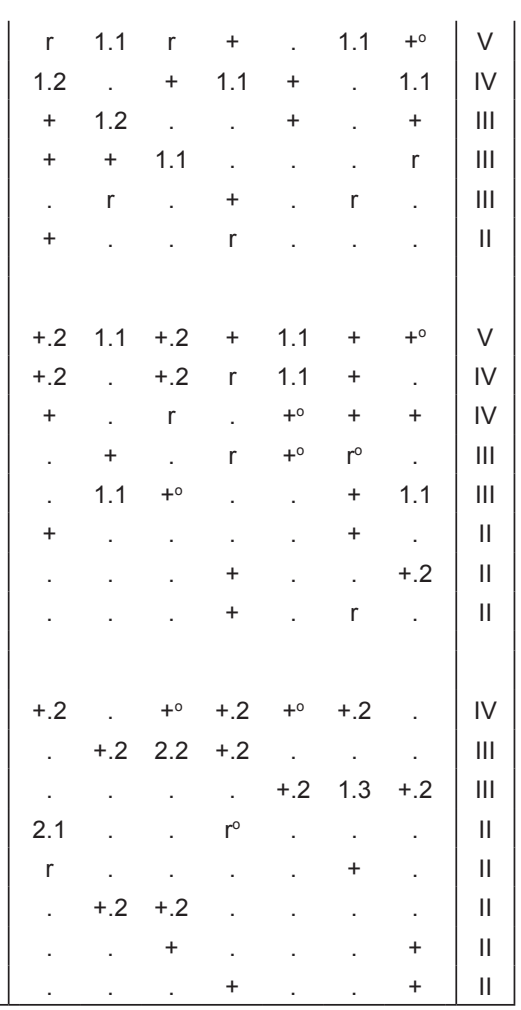

Taksony sporadyczne z tabeli 4 (Sporadic taxa from Table 4): II: Androsace septentrionalis 5(r); Cerastium glutinosum 7(1.2); III: Chondrilla juncea 4(+); Corynephorus canecsens 7(+); Festuca ovina 7(+); Jasione montana 7(1.2); Sedum reflexum 6(+); Veronica dillenii 6(+); Vulpia myuros 7(+); IV: Petrorhagia prolifera 6(+); Poa angustifolia var. collina 1(+); Poa compressa 6(+); Verbascum lychnitis 3(r); V: Eragrostis minor 5(+); Euphorbia helioscopia 3(r); Papaver argemone 2(r); Papaver dubium 1(+); Setaria viridis 5(+); Veronica triphyllos 6(r); Vicia angustifolia 6(1.1); Vicia tetrasperma 7(r); Vicia villosa 5(+); VI: Artemisia vulgaris 2(r); Ballota nigra s.s. 3(+); Medicago xvaria 2(+); Melandrium album 3(+); Melilotus officinalis 4(r); Oenothera rubricaulis 6(+); Saponaria officinalis 3(r); Verbascum thapsus 6(+); VII: Bryum argenteum 3(1.2); Capsella bursa-pastoris var. pinnatifida 3(+); Cardaminopsis arenosa 3(+); Dactylis glomerata 3(+); Funaria hygrometrica 3(+); Hypericum perforatum 2(+); Rhynchostegium megapolitanum $7(+)$.

diagnostycznych, zlokalizowane były głównie wokół zabudowań Wydziału Nauk Geograficznych i Geologicznych oraz Wydziału Fizyki, a poza tym (m.in. między budynkami Wydziału Biologii i Wydziału Chemii) występowały na małych powierzchniach i w rozproszeniu. Z obserwacji autorów wynika, iż po dwóch latach fitocenozy tego typu ustąpiły z terenu badań prawie całkowicie. Omawiane zbiorowisko, w stosunku do pozostałych muraw związku Sileno conicae-Cerastion semidecandri, zdawało się preferować siedliska wyraźnie bardziej i niedawno zaburzone, zwykle położone na stokach o różnym nachyleniu. Stanowiąc pionierską, inicjalną fazę rozwoju roślinności na obszarach poinwestycyjnych, charakteryzowany typ murawy wykazuje lokalnie tendencję do gwałtownego pomniejszania areału, ustępując miejsca m.in. fitocenozom Arenario-Sedetum acris. 


\section{Sileno conicae-Cerastietum semidecandri (tab. 5; tab. 6, kol. 6)}

Ch. Ass. (reg.): Silene conica; D. Ass. (reg.): Bromus hordeaceus, Poa bulbosa var. vivipara

Struktura i skład florystyczny. Struktura fitocenoz zespołu lepnicy smukłej i rogownicy pięciopręcikowej jest zasadniczo dwuwarstwowa. Warstwa zielna jest dość luźna; pokrywa 50-70\% (średnio 62\%) powierzchni zdjęcia, lecz zawsze wyraźnie przeważa nad mszystą (5-40\%, średnio 22\%). O jej charakterystycznej fizjonomii decyduje w okresie optimum rozwoju zbiorowiska, przypadającego na pełnię wiosny i początek lata, liczny udział różowo kwitnącej, dorastającej do około $15 \mathrm{~cm}$ wysokości Silene conica, która przerastają wiechy Bromus hordeaceus, Poa angustifolia (ryc. 7), a lokalnie też (np. w rynnie jezior konińskich; Wojterska i in. 2015) P. bulbosa var. vivipara. Na terenie kampusu UAM stałym elementem zbiorowiska jest ponadto biało kwitnący Anthemis arvensis. W aspekcie wczesnowiosennym w płatach tych, trudnych wówczas do odróżnienia od Myosotido strictae-Arabidopsietum thalianae, panują terofity charakterystyczne i wyróżniające związku Sileno conicae-Cerastion semidecandri. W ubogiej florystycznie warstwie mszystej gatunkiem panującym jest zawsze Brachythecium albicans.

W składzie asocjacji, obok zdecydowanie przeważających gatunków murawowych z klas Koelerio-Corynephoretea i Festuco-Brometea, znaczącą domieszkę stanowią rośliny synantropijne.

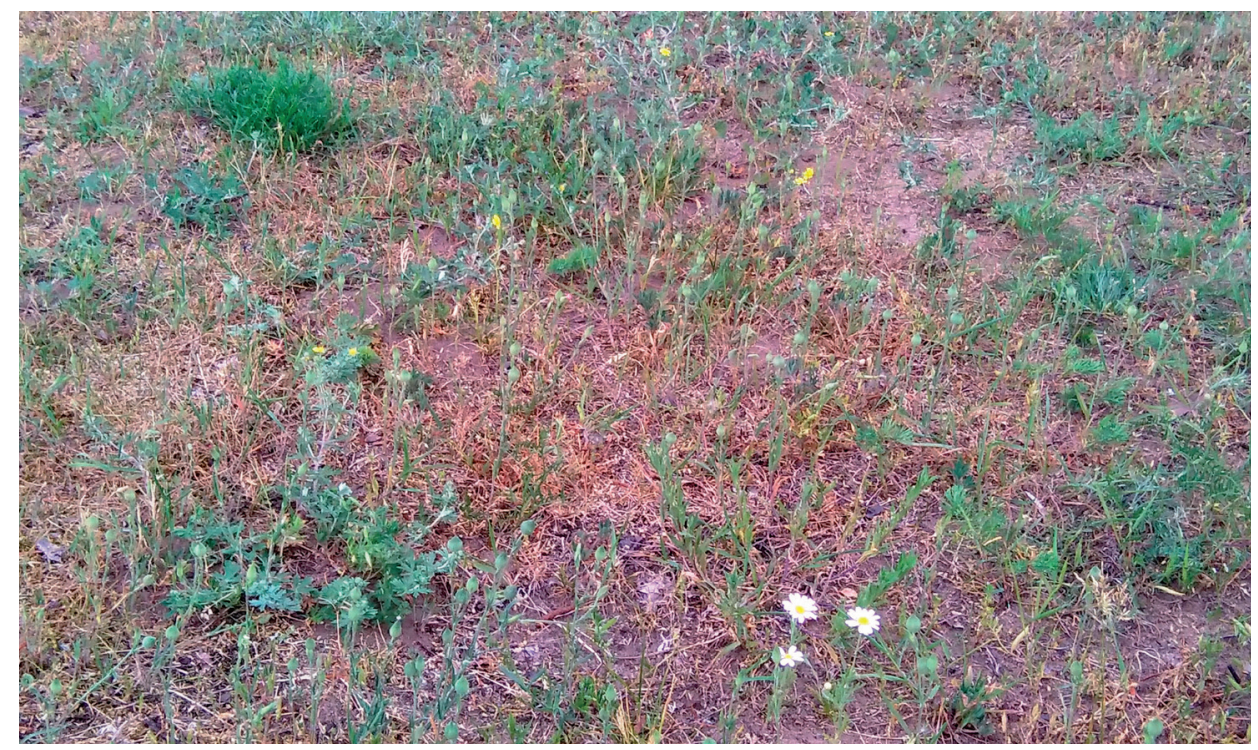

Ryc. 7. Fragment płatu Sileno conicae-Cerastietum semidecandri na tyłach kompleksu sportowego we wschodniej części kampusu. Fot. T. Szygendowski, 30.05.2016 r.

Fig. 7. Fragment of a patch of the Sileno conicae-Cerastietum semidecandri behind the sports complex in the eastern part of the campus. Phot. T. Szygendowski, 30.05.2016 
Tabela 5 - Table 5

Sileno conicae-Cerastietum semidecandri Korneck 1974

\begin{tabular}{|c|c|c|c|c|c|c|c|c|}
\hline \multirow[t]{2}{*}{ Numer kolejny - } & Successive No. & 1 & 2 & 3 & 4 & 5 & 6 & \multirow{10}{*}{ 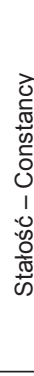 } \\
\hline & dzień (day) & 30 & 30 & 30 & 30 & 08 & 08 & \\
\hline \multirow{2}{*}{\multicolumn{2}{|c|}{$\begin{array}{l}\text { miesiąc (month) } \\
\text { rok (year) } 20 . .\end{array}$}} & 05 & 05 & 05 & 05 & 06 & 06 & \\
\hline & & 16 & 16 & 16 & 16 & 15 & 15 & \\
\hline \multicolumn{2}{|c|}{ Pokrycie warstwy zielnej c \% } & 60 & & & & & & \\
\hline \multicolumn{2}{|c|}{ Cover of herb layer } & 60 & 50 & 65 & bU & 65 & 10 & \\
\hline \multicolumn{2}{|c|}{ Pokrycie warstwy mszystej d \% } & 10 & 5 & 35 & 25 & 15 & 10 & \\
\hline \multicolumn{2}{|c|}{ Cover of moss layer } & 40 & 5 & 35 & 25 & 15 & 10 & \\
\hline \multicolumn{2}{|c|}{ Powierzchnia zdjęcia - Area of relevé $\left[\mathrm{m}^{2}\right]$} & 9 & 12 & 15 & 10 & 10 & 8 & \\
\hline \multicolumn{2}{|c|}{ Liczba taksonów - Number of taxa } & 38 & 37 & 34 & 33 & 32 & 29 & \\
\hline \multicolumn{9}{|l|}{ I. Ch., *D. Ass. } \\
\hline \multicolumn{2}{|l|}{ Silene conica } & 2.1 & 2.1 & 2.1 & 2.1 & 3.1 & 2.1 & V \\
\hline \multicolumn{2}{|c|}{${ }^{*}$ Bromus hordeaceus } & 1.1 & 1.1 & 1.1 & 1.1 & 2.1 & 1.2 & V \\
\hline \multicolumn{9}{|c|}{ II. Ch., *D. Sileno conicae-Cerastion semidecandri } \\
\hline \multicolumn{2}{|c|}{ Cerastium semidecandrum } & 2.1 & 2.2 & 3.1 & 2.2 & 2.2 & 4.4 & V \\
\hline \multicolumn{2}{|c|}{ Arenaria serpyllifolia } & 2.1 & 1.1 & 1.1 & 2.1 & 2.1 & 2.1 & V \\
\hline \multicolumn{2}{|c|}{ Erophila verna fo. } & + & + & 2.1 & 1.1 & +.2 & 1.2 & V \\
\hline \multicolumn{2}{|c|}{${ }^{*}$ Bromus tectorum } & + & 1.3 & +0 & + & + & 1.2 & V \\
\hline \multicolumn{2}{|c|}{ Holosteum umbellatum } & 1.1 & 1.1 & + & + & . & $r$ & V \\
\hline \multicolumn{2}{|c|}{${ }^{\star}$ Erodium cicutarium } & $r$ & + & . & + & + & +o & V \\
\hline \multicolumn{2}{|c|}{ Cerastium glutinosum } & . & + & . & + & . & . & II \\
\hline \multicolumn{9}{|c|}{ III. Ch. Koelerio-Corynephoretea } \\
\hline \multicolumn{2}{|c|}{ Brachythecium albicans } & 3.4 & 1.2 & 3.4 & 2.3 & 2.3 & 1.2 & V \\
\hline Trifolium arvens & & 2.2 & 2.1 & 2.2 & 2.2 & 2.1 & 1.1 & V \\
\hline Potentilla argen & tea & 2.2 & +.2 & 1.2 & +.2 & +.2 & +.2 & V \\
\hline Vicia lathyroides & & 1.1 & + & 1.1 & 2.1 & + & 1.1 & V \\
\hline Helichrysum are & enarium & 1.3 & 2.3 & +.2 & +.2 & 1.2 & . & V \\
\hline Scleranthus per & rennis & . & +.2 & +.2 & +.2 & . & +.2 & IV \\
\hline Rumex tenuifoli & & + & $r$ & + & . & +.2 & . & IV \\
\hline Ceratodon purp & ureus & . & . & . & +.2 & +.2 & 1.2 & III \\
\hline Veronica dillenii & & + & + & . & + & . & . & III \\
\hline Chondrilla junce & & + & . & +.2 & . & . & . & II \\
\hline Scleranthus pol & ycarpos & . & $r$ & + & . & . & . & II \\
\hline Sedum acre & & . & r & . & . & +.2 & . & ॥ \\
\hline IV. Ch. Festuco- & Brometea & & & & & & & \\
\hline Artemisia camp & estris s.s. & 2.2 & 1.2 & 2.2 & 2.2 & 1.2 & 1.2 & V \\
\hline Poa angustifolia & var. collina & 1.2 & +.2 & 1.2 & 2.2 & +.2 & +.2 & V \\
\hline Achillea pannon & nica & 1.2 & 1.2 & +.2 & +.2 & . & +.2 & V \\
\hline Euphorbia cypa & rissias & +.2 & . & $+\circ$ & +0 & +0 & $\cdot$ & IV \\
\hline Petrorhagia pro & lifera & . & + & . & . & + & 1.1 & III \\
\hline Festuca trachyp & hylla & 1.2 & . & . & $+\circ$ & . & +.2 & III \\
\hline Syntrichia rurali & & +.2 & . & 1.2 & +.2 & . & . & III \\
\hline Centaurea stoe & & + & + & . & + & . & . & III \\
\hline Poa compressa & & + & . & + & . & . & . & II \\
\hline V. Ch. Stellariete & a mediae & & & & & & & \\
\hline Anthemis arven & sis & 1.1 & 2.1 & + & 1.2 & +.2 & +.2 & V \\
\hline
\end{tabular}




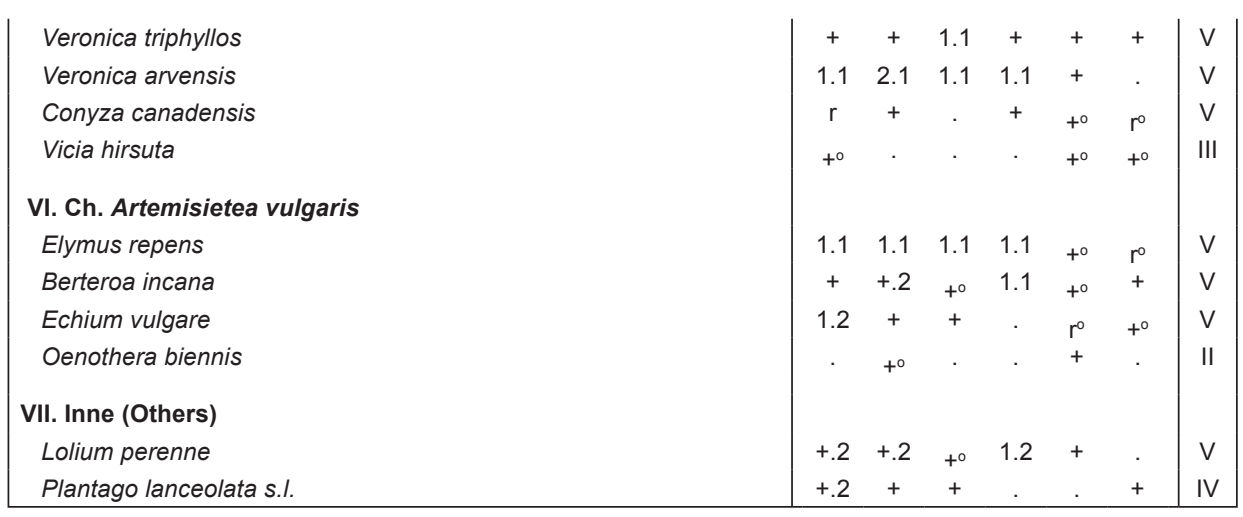

Taksony sporadyczne z tabeli 5 (Sporadic taxa from Table 5): II: Arabidopsis thaliana 3(+); III: Corynephorus canescens 6(+); Jasione montana 5(+); Rumex acetosella s.s. 4(+); Trifolium campestre 2(+); IV: Achillea collina $3(+)$; V: Vicia angustifolia 5(r); Vicia villosa 5(+); Viola arvensis 1(r); VI: Cichorium intybus 2(r); Convolvulus arvensis 1(+); Erigeron annuus 3(r); Melandrium album 2(r); Tragopogon dubius 3(r); Verbascum thapsus 1(r); VII: Bryum caespiticium 6(+); Festuca rubra 4(+); Poa pratensis s.s. 1(+).

Lokalnie na kampusie UAM Morasko płaty Sileno conicae-Cerastietum semidecandri wykazują dość duże bogactwo gatunkowe (w zdjęciach notowano 29-38, przeciętnie 34 taksony roślin), odbiegając pod tym względem od większości materiałów z regionu Wielkopolski (por. tab. 6).

Zróżnicowanie. Udokumentowane na obszarze badań fitocenozy charakteryzowanego zespołu cechują się niewielkim zróżnicowaniem składu gatunkowego, polegającym głównie na wahaniach bogactwa florystycznego, i nie odpowiadają ściśle niższej rangi syntaksonom wyróżnianym w literaturze niemieckiej (Korneck 1974, 1978; Passarge 1996). Dla wyjaśnienia kwestii wewnętrznej zmienności w obrębie tej jednostki wymagane jest zgromadzenie bogatszego materiału fitosocjologicznego.

Rozmieszczenie i lokalne warunki występowania. Fitocenozy Sileno conicae-Cerastietum semidecandri dokumentowali z Wielkopolski i terenów przyległych dość liczni autorzy (Rakowski 1996; Brzeg, Janyszek 1997; Ratyńska 2001; Skrzypczak 2007; Zgrabczyńska, Brzeg 2009; Wojterska i in. 2015), a wcześniej, w randze zbiorowiska z Silene conica, Głowacki (1984). Lokalnie, w skali kampusu UAM, zespół stanowi rzadki element roślinności murawowej. Jego płaty stwierdzono jedynie w północno-wschodniej części badanego terenu, w obrębie otwartych powierzchni na tyłach kompleksu sportowego, gdzie, jak wynika z corocznych obserwacji, sukcesywnie poszerza swój zasięg. Murawa ta wykazuje związek z podłożami piaszczysto-gliniastymi, porastając miejsca poddawane umiarkowanemu, lecz dość systematycznemu wydeptywaniu, tworząc kompleks przestrzenny ze zbiorowiskami dywanowymi z klasy Polygono-Poetea annuae, murawami szczotlichowymi ze związku Corynephorion canescentis i bardziej trwałymi murawami ze związku Thero-Airion (Sclerantho-Herniarietum glabrae i Armerio-Festucetum). 
Synoptyczna tabela zbiorowisk związku Sileno conicae-Cerastion semidecandri (tab. 6), w której uwzględniono 101 zdjęć fitosocjologicznych z Wielkopolski i Ziemi Lubuskiej, dobrze ilustruje przyjęte za Ratyńską i in. (2010) ujęcie syntaksonomiczne znanych wcześniej z Polski syntaksonów. Pozwala także zweryfikować bądź uzupełnić adekwatne w skali regionu listy gatunków diagnostycznych (charakterystycznych i wyróżniających) dla poszczególnych jednostek. W tabeli tej ujawniła się ponadto wyraźnie (kol. 3) pozycja zespołu Myosotido strictae-Arabidopsietum thalianae jako asocjacji centralnej związku.

Odrębność wyróżnionych asocjacji dobrze ilustrują także wyniki analizy składowych głównych (PCA), obejmującej materiały oryginalne z kampusu UAM Morasko (ryc. 8). Punkty reprezentujące zespoły: Cerastio semidecandri-Androsacetum septentrionalis (1-8; niebieskie kółka), Erodio-Senecionetum

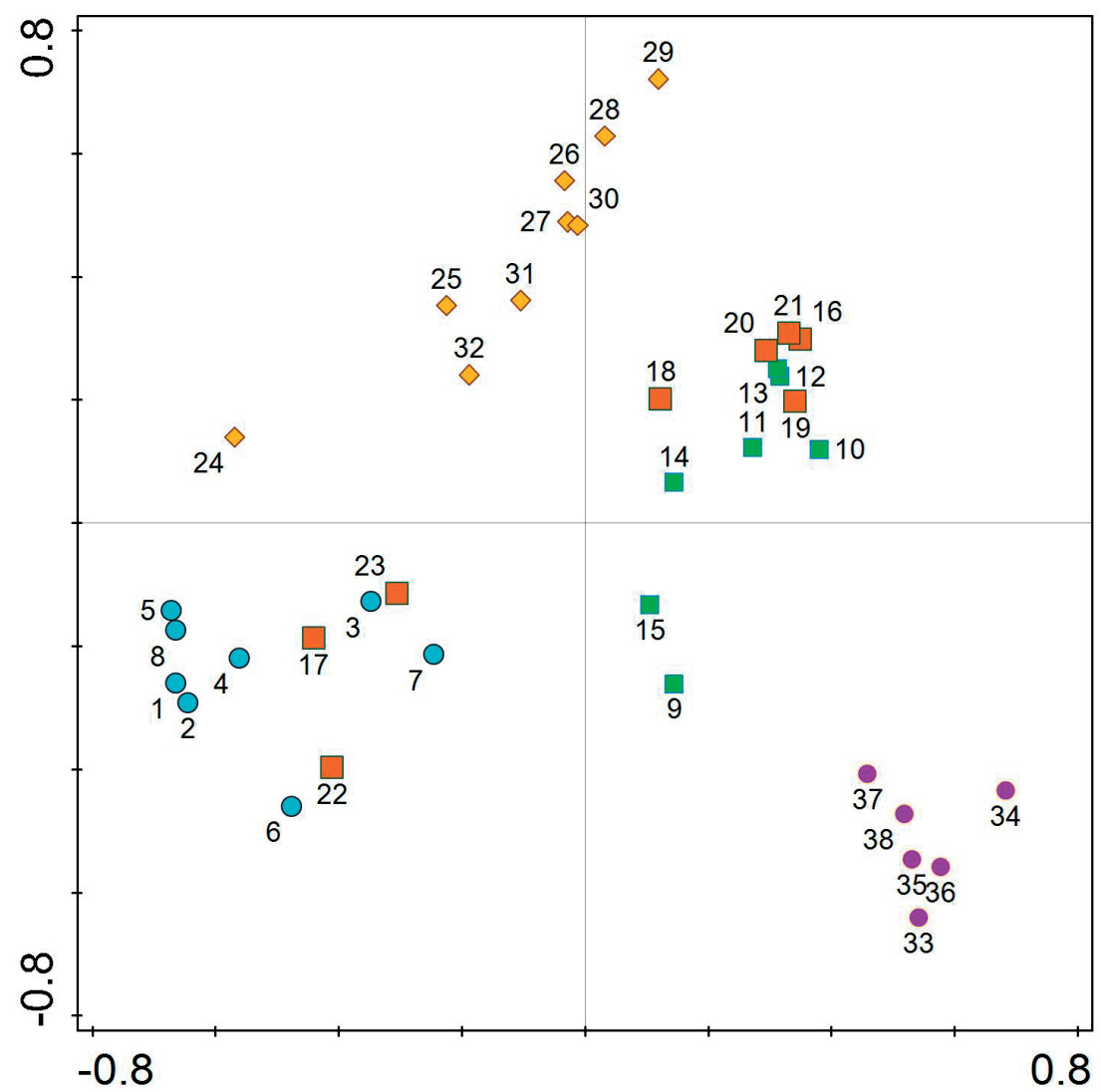

Ryc. 8. Diagram PCA dla pięciu badanych zespołów; objaśnienia w tekście

Fig. 8. PCA diagram for five examined associations: Cerastio semidecandri-Androsacetum septentrionalis (1-8; blue circles), Erodio-Senecionetum vernalis (9-15; green squares), Myosotido strictae-Arabidopsietum thalianae (16-23; brown squares), Arenario-Sedetum acris (24-32; yellow diamonds), Sileno conicae-Cerastietum semidecandri (33-38; violet circles) 
Tabela 6 - Table 6

Tabela synoptyczna zbiorowisk związku Sileno conicae-Cerastion semidecandri

z Wielkopolski

Synoptic table of communities of the Sileno conicae-Cerastion semidecandri alliance from the Wielkopolska region

\begin{tabular}{|c|c|c|c|c|c|c|c|c|c|c|c|c|}
\hline Numer kolejny - Successive No. & \multicolumn{2}{|c|}{1} & \multicolumn{2}{|c|}{2} & \multicolumn{2}{|c|}{3} & \multicolumn{2}{|c|}{4} & \multicolumn{2}{|c|}{5} & \multicolumn{2}{|l|}{6} \\
\hline Liczba zdjęć - Number of relevés & \multicolumn{2}{|c|}{15} & \multicolumn{2}{|c|}{12} & \multicolumn{2}{|c|}{14} & \multicolumn{2}{|c|}{18} & \multicolumn{2}{|c|}{15} & \multicolumn{2}{|c|}{27} \\
\hline Liczba taksonów - Number of taxa & \multicolumn{2}{|c|}{99} & \multicolumn{2}{|c|}{101} & \multicolumn{2}{|c|}{122} & \multicolumn{2}{|c|}{118} & \multicolumn{2}{|c|}{134} & \multicolumn{2}{|c|}{138} \\
\hline $\begin{array}{l}\text { Liczba taksonów w zdjęciu } \\
\text { Number of taxa in relevé }\end{array}$ & \multicolumn{2}{|c|}{$25-38$} & \multicolumn{2}{|c|}{$26-43$} & $23-$ & & $12-$ & & $20-4$ & & $14-5$ & \\
\hline $\begin{array}{l}\text { Średnia liczba taksonów w zdjęciu } \\
\text { Average number of taxa in relevé }\end{array}$ & 32 & & 35 & & 31 & & 27 & & 35 & & 27 & \\
\hline I. Ch., "D. Ass. et Subass. & & & & & & & & & & & & \\
\hline Androsace septentrionalis & 100 & +-3 & 100 & +-2 & - & & 11 & $\mathrm{r}-\mathrm{+}$ & 7 & $\mathrm{r}$ & - & \\
\hline${ }^{*}$ Pinus sylvestris b/c & 73 & +-1 & 67 & +-1 & 14 & $r$ & 6 & + & 13 & $r-+$ & 7 & + \\
\hline${ }^{*}$ Calamagrostis epigejos & 67 & +-1 & 58 & $r-1$ & 14 & + & - & & - & & 7 & + \\
\hline Thymus serpyllum (III) & - & & 92 & +-2 & - & & - & & - & & - & \\
\hline Potentilla arenaria (IV) & - & & 58 & +.2 & - & & 16 & + & 13 & 1 & - & \\
\hline Cladonia chlorophaea & 13 & + & 50 & + & - & & - & & 7 & + & - & \\
\hline Silene chlorantha (III) & - & & 50 & +-1 & - & & 11 & 1 & - & & - & \\
\hline Cladonia glauca & - & & 42 & + & - & & - & & 13 & +-2 & - & \\
\hline Niphotrichum canescens (III) & 7 & 1 & 42 & +-2 & - & & - & & - & & - & \\
\hline Galium verum s.s. (IV) & - & & 42 & +-1 & - & & - & & - & & 4 & + \\
\hline Cetraria aculeata (III) & - & & 25 & +-1 & - & & - & & 7 & + & - & \\
\hline Carex praecox (IV) & - & & 25 & +-2 & - & & 6 & + & - & & - & \\
\hline Cephaloziella divaricata (III) & - & & 25 & + & - & & - & & - & & - & \\
\hline Festuca psammophila (III) & - & & 17 & + & - & & - & & - & & - & \\
\hline Koeleria glauca (III) & - & & 17 & + & - & & - & & - & & - & \\
\hline Sedum acre (loc. opt.) & 87 & +-2 & 83 & +-1 & 36 & +-1 & 100 & $2-5$ & 53 & +-1 & 44 & $r-3$ \\
\hline *Medicago lupulina (V) & 7 & + & - & & 14 & +-1 & 67 & +-2 & 13 & + & 26 & + \\
\hline${ }^{*}$ Achillea collina (IV) & & & & & & & 44 & +-2 & & & 4 & + \\
\hline Trifolium dubium (VII) & - & & - & & - & & 17 & +-1 & - & & - & \\
\hline Senecio vernalis & 40 & $r-+$ & 33 & +-1 & 7 & $r$ & 11 & r- & 100 & $1-3$ & 4 & + \\
\hline${ }^{*}$ Erodium cicutarium $(\mathrm{VI})$ & - & & 8 & $\mathrm{r}$ & 29 & +-2 & 22 & $r-+$ & 73 & +-2 & 33 & $r-+$ \\
\hline${ }^{*}$ Veronica hederifolia (VI) & - & & - & & 7 & + & - & & 27 & $r-1$ & 4 & $\mathrm{r}$ \\
\hline${ }^{*}$ Allium vineale & - & & - & & - & & - & & 20 & + & - & \\
\hline${ }^{*}$ Sisymbrium loeselii (VI) & - & & 8 & $r$ & - & & - & & 20 & $r-+$ & 4 & $r$ \\
\hline * Lamium purpureum (VI) & - & & 8 & + & - & & - & & 20 & +-2 & - & \\
\hline Silene conica & - & & - & & - & & - & & - & & 100 & +-3 \\
\hline${ }^{*}$ Bromus hordeaceus (VII) & - & & - & & 36 & +-1 & 22 & +-1 & 20 & + & 74 & +-2 \\
\hline${ }^{*}$ Poa bulbosa var. vivipara (IV) & - & & - & & 7 & + & - & & - & & 11 & 1 \\
\hline II. Ch., *D. All. Sileno conicae-Ce & emide & can & & & & & & & & & & \\
\hline Cerastium semidecandrum & 100 & +-4 & 100 & $1-3$ & 100 & $2-4$ & 83 & +-3 & 100 & +-4 & 89 & +-4 \\
\hline Erophila verna & 93 & +-2 & 83 & +-2 & 100 & $r-3$ & 67 & +-2 & 73 & $\mathrm{r}-2$ & 41 & $r-2$ \\
\hline Holosteum umbellatum & 40 & +-1 & 33 & + & 79 & +-3 & 56 & +-2 & 53 & +-1 & 37 & $r-1$ \\
\hline Arenaria serpyllifolia & 53 & $r-1$ & 50 & $r-1$ & 57 & $\mathrm{r}-2$ & 89 & +-2 & 87 & +-2 & 74 & +-2 \\
\hline${ }^{*}$ Bromus tectorum $(\mathrm{VI})$ & 67 & $r-1$ & 50 & $r-2$ & 29 & +-2 & 28 & $r-1$ & 67 & +-2 & 67 & $r-2$ \\
\hline Myosotis stricta & 53 & +-1 & 33 & + & 71 & $r-2$ & 28 & +-2 & 73 & $r-2$ & 19 & $r-1$ \\
\hline${ }^{*}$ Arabidopsis thaliana (VI) & 40 & $r-1$ & 25 & + & 57 & $r-2$ & 22 & $r-1$ & 60 & +-1 & 4 & + \\
\hline Cerastium glutinosum & 13 & + & - & & 29 & +-1 & - & & 7 & 1 & 7 & + \\
\hline III. Ch. Koelerio-Corynephoretea & & & & & & & & & & & & \\
\hline Ceratodon purpureus & 100 & $1-4$ & 100 & +-4 & 100 & +-3 & 94 & +-4 & 93 & +-3 & 67 & +-2 \\
\hline
\end{tabular}


Brachythecium albicans Trifolium arvense

Helichrysum arenarium

Rumex tenuifolius

Rumex acetosella s.s.

Vicia lathyroides

Corynephorus canescens

Jasione montana

Veronica dilenii

Trifolium campestre

Scleranthus perennis

Chondrilla juncea

Polytrichum piliferum

Placynthiella oligotropha

Festuca ovina

Spergula morisonii

Peltigera didactyla

Plantago arenaria

Cladonia subulata

Cladonia furcata var. palamaea

Potentilla argentea s.s.

Hypochoeris radicata

Veronica verna

Scleranthus polycarpos

\section{Ch. Festuco-Brometea}

Artemisia campestris

Festuca trachyphylla

Achillea pannonica

Centaurea stoebe

Syntrichia ruralis

Poa angustifolia var. collina

Poa compressa

Euphorbia cyparissias

Petrorhagia prolifera

Medicago minima

Medicago falcata

\section{Ch. Artemisietea vulgaris}

\section{Berteroa incana}

Oenothera biennis

Elymus repens

Convolvulus arvensis

Artemisia vulgaris

Tragopogon dubius

Picris hieracioides

Oenothera rubricaulis

Melandrium album

Euphorbia esula

Echium vulgare

Daucus carota

\section{Ch. Stellarietea mediae}

Conyza canadensis

Vicia hirsuta

Viola arvensis

Vicia angustifolia

\begin{tabular}{|c|c|c|c|c|c|c|c|c|c|c|c|}
\hline 87 & +-5 & 100 & +-3 & 93 & $1-4$ & 94 & +-4 & 93 & +-3 & 41 & +-3 \\
\hline 100 & +-2 & 83 & +-1 & 64 & $1-2$ & 83 & +-2 & 73 & +-2 & 89 & +-2 \\
\hline 73 & +-4 & 92 & +-2 & 64 & +-2 & 61 & +-2 & 87 & +-3 & 30 & +-2 \\
\hline 87 & +-2 & 67 & $r-2$ & 57 & +-2 & 56 & $r-2$ & 40 & +-1 & 37 & $r-1$ \\
\hline 27 & +-1 & 50 & + & 64 & +-2 & 50 & +-1 & 67 & +-1 & 37 & +-2 \\
\hline 53 & r-t & 50 & + & 43 & +-1 & 28 & $r-1$ & 53 & $r-1$ & 37 & +-2 \\
\hline 87 & $r-3$ & 100 & +-2 & 43 & +-1 & 28 & +-2 & 47 & +-2 & 37 & $r-2$ \\
\hline 67 & +-1 & 75 & +-1 & 36 & +-2 & 28 & +-1 & 53 & +-2 & 7 & + \\
\hline 67 & $r-1$ & 42 & +-1 & 21 & +-1 & 22 & $r-1$ & 47 & $r-2$ & 41 & $r-1$ \\
\hline 27 & +-1 & 33 & + & 36 & +-1 & 50 & +-1 & 40 & +-1 & 30 & +-2 \\
\hline 20 & $r-1$ & 17 & + & 21 & +-1 & 11 & +-2 & 7 & + & 26 & + \\
\hline 33 & $\mathrm{r}-\mathrm{t}$ & 25 & +-1 & 7 & r & 22 & + & 7 & + & 15 & + \\
\hline 33 & +-1 & 83 & +-2 & 36 & +-2 & 6 & + & 7 & 1 & 4 & + \\
\hline 20 & + & 8 & + & 14 & + & 6 & 1 & - & & - & \\
\hline 7 & + & - & & 14 & + & 17 & +-2 & 7 & + & - & \\
\hline 7 & r & 8 & + & 14 & + & 6 & + & - & & - & \\
\hline 20 & +-1 & 8 & + & - & & 6 & + & - & & - & \\
\hline 33 & +-1 & - & & - & & 11 & + & - & & 4 & + \\
\hline 60 & +-1 & 92 & +-2 & 14 & + & 11 & + & 13 & +-1 & - & \\
\hline 27 & +-1 & 42 & +-1 & 14 & +-2 & - & & 7 & + & - & \\
\hline 7 & + & - & & 57 & +-1 & 33 & +-2 & 20 & +-1 & 56 & +-2 \\
\hline - & & 8 & + & 36 & $r-1$ & 33 & $r-1$ & 33 & $r-1$ & 19 & r-t \\
\hline - & & - & & 21 & 1 & 11 & $r-1$ & 20 & r-t & 15 & $r-1$ \\
\hline - & & - & & 21 & $1-2$ & - & & 7 & 2 & 22 & $r-1$ \\
\hline 100 & +-2 & 92 & $\mathrm{r}-1$ & 57 & +-2 & 89 & +-1 & 60 & +-2 & 70 & $r-2$ \\
\hline 73 & +-2 & 83 & +-2 & 36 & +-2 & 50 & +-2 & 33 & +-2 & 48 & +-1 \\
\hline 40 & +-1 & 25 & $\mathrm{r-n}$ & 57 & $r-2$ & 39 & +-1 & 67 & $r-1$ & 30 & +-1 \\
\hline 87 & $\mathrm{r}-2$ & 67 & +-2 & 29 & $r-2$ & 22 & +-1 & 53 & +-2 & 33 & +-2 \\
\hline 60 & +-2 & 50 & +-2 & 29 & +-2 & 28 & + & 40 & +-2 & 11 & +-1 \\
\hline 20 & +-1 & 33 & +-2 & 21 & +-2 & 28 & +-1 & 20 & + & 44 & +-2 \\
\hline 53 & +-1 & 8 & 1 & 14 & + & 28 & + & 13 & + & 22 & $r-1$ \\
\hline 20 & + & 42 & + & 29 & $r-1$ & 11 & $\mathrm{r}-\mathrm{+}$ & 20 & +-1 & 15 & + \\
\hline 27 & $\mathrm{r}-\mathrm{+}$ & - & & - & & 6 & r & 20 & +-1 & 30 & +-1 \\
\hline 40 & +-2 & - & & - & & 17 & +-2 & 20 & +-1 & - & \\
\hline- & & 17 & $=-1$ & - & & 6 & + & 7 & + & 4 & + \\
\hline 40 & $r-+$ & 33 & +-1 & 29 & +-1 & 33 & $\mathrm{r}-\mathrm{+}$ & 73 & $r-1$ & 67 & +-1 \\
\hline 40 & $r-+$ & 17 & $r-+$ & 36 & $r-+$ & 39 & $r-1$ & 47 & $r-1$ & 19 & + \\
\hline 20 & $r-+$ & 8 & + & 64 & $r-1$ & 33 & +-2 & 60 & $r-1$ & 48 & $r-1$ \\
\hline 13 & +-1 & 25 & r-- & 36 & + & 11 & +-1 & 20 & +-1 & 22 & $r-+$ \\
\hline 13 & + & 8 & + & 7 & + & 11 & + & 27 & $\mathrm{r}-\mathrm{+}$ & 22 & $r-+$ \\
\hline 13 & + & 25 & r-t & 7 & + & 11 & r & 13 & $\mathrm{r-t}$ & 19 & $r-+$ \\
\hline 13 & +-1 & 8 & + & - & & 11 & $r-+$ & 20 & $r-1$ & 7 & + \\
\hline 40 & $r-1$ & 33 & +-2 & - & & 6 & $r$ & 13 & + & 4 & $r$ \\
\hline- & & - & & 21 & r-t & 28 & r-t & 13 & $\mathrm{r}-\mathrm{+}$ & 15 & r-t \\
\hline - & & - & & 14 & $r-+$ & - & & 13 & + & 4 & + \\
\hline 13 & $r$ & 8 & $r$ & - & & 11 & r & 67 & $r-1$ & 37 & $r-1$ \\
\hline- & & - & & 7 & + & 11 & r-- & 40 & +-1 & 26 & $r-1$ \\
\hline 33 & $r-1$ & 25 & $\mathrm{r}-1$ & 29 & $\mathrm{r}-\mathrm{+}$ & 50 & $r-1$ & 80 & $r-2$ & 59 & $r-1$ \\
\hline 60 & $r-+$ & 33 & $r-+$ & 43 & r-t & 17 & r-- & 60 & +-1 & 26 & $r-1$ \\
\hline 20 & $r-+$ & 25 & + & 21 & $r-{ }^{*}$ & 17 & $\mathrm{r}-\mathrm{+}$ & 40 & $r-1$ & 15 & $r-+$ \\
\hline 7 & + & 8 & $r$ & 21 & $r-z^{*}$ & 6 & + & 7 & 1 & 22 & $r-1$ \\
\hline
\end{tabular}




\begin{tabular}{|c|c|c|c|c|c|c|c|c|c|c|c|c|}
\hline Setaria viridis & 13 & + & - & & 7 & 1 & 6 & $\mathrm{r}$ & 20 & + & - & \\
\hline Papaver dubium & - & & 8 & $\mathrm{r}$ & 29 & $r-1$ & 17 & $r-+$ & 13 & $r-+$ & - & \\
\hline Veronica arvensis & 7 & $r$ & - & & 50 & $r-2$ & 44 & $r-1$ & 40 & +-1 & 41 & $r-2$ \\
\hline Capsella bursa-pastoris var. integrifolia & - & & - & & 21 & r-t+ & 6 & $r$ & 27 & $r-1$ & 7 & + \\
\hline Veronica triphyllos & - & & - & & 21 & r-t+ & 6 & + & 13 & r-t+ & 30 & $r-1$ \\
\hline Lepidium densiflorum & - & & - & & 7 & + & 6 & + & 7 & + & 19 & r-t+ \\
\hline Papaver argemone & - & & - & & - & & 11 & r & 20 & $r-+$ & 7 & r-t+ \\
\hline Anthemis arvensis & - & & - & & 7 & 1 & - & & 27 & +-1 & 22 & +-2 \\
\hline Apera spica-venti & - & & - & & - & & - & & 20 & $r-1$ & 26 & +-1 \\
\hline \multicolumn{13}{|l|}{ VII. Ch. Molinio-Arrhenatheretea } \\
\hline Carex hirta & 27 & $\mathrm{r}-2$ & 50 & $r-2$ & 7 & + & 6 & + & 20 & $r-2$ & 19 & $r-2$ \\
\hline Taraxacum officinale agg. & 7 & $r$ & 8 & + & 21 & r & 17 & + & 20 & $r-+$ & 19 & $r-1$ \\
\hline Festuca rubra & 40 & + & - & & 36 & +-1 & 50 & +-2 & 40 & + & 19 & +-2 \\
\hline Rumex acetosa & 13 & + & - & & 29 & + & 11 & $r-+$ & 7 & 2 & 11 & + \\
\hline Poa pratensis s.s. & 7 & + & 8 & + & 14 & $r-+$ & 11 & + & - & & 11 & + \\
\hline Plantago lanceolata & - & & - & & 50 & +-2 & 56 & $r-2$ & 27 & + & 48 & $r-2$ \\
\hline Lolium perenne & - & & - & & 36 & +-1 & 28 & + & 33 & + & 63 & +-1 \\
\hline Dactylis glomerata & - & & - & & 14 & + & 11 & + & 20 & +-1 & 11 & + \\
\hline Holcus lanatus & - & & - & & 14 & +-1 & - & & 20 & + & 11 & + \\
\hline Achillea millefolium & 7 & + & - & & 14 & + & - & & - & & 30 & +-2 \\
\hline Trifolium repens & - & & - & & - & & 11 & + & - & & 19 & r-t+ \\
\hline \multicolumn{13}{|l|}{ VIII. Inne (Others) } \\
\hline Hieracium pilosella & 47 & +-3 & 33 & +-1 & 57 & +-2 & 50 & +-2 & 47 & +-1 & 19 & $r-1$ \\
\hline Bryum caespiticium & 33 & +-1 & 42 & +-1 & 29 & +-1 & 33 & +-2 & 33 & +-2 & 22 & +-2 \\
\hline Agrostis capillaris & 7 & + & - & & 21 & +-3 & 6 & + & 7 & 3 & 26 & $r-2$ \\
\hline Silene vulgaris & 7 & + & 17 & + & - & & - & & 13 & + & 7 & r-t+ \\
\hline Rhynchostegium megapolitanum & - & & 17 & + & 14 & +-2 & - & & 7 & + & - & \\
\hline Cladonia fimbriata & 53 & r-t & 42 & +-1 & 14 & + & - & & 13 & + & - & \\
\hline Cetraria islandica & 7 & + & 17 & +-1 & - & & - & & - & & - & \\
\hline Bryum argenteum & 7 & + & - & & 29 & + & 11 & + & 7 & 1 & 7 & + \\
\hline Poa annua & - & & - & & 29 & + & - & & - & & 7 & + \\
\hline Hypericum perforatum & - & & - & & 21 & + & 6 & + & 7 & + & 4 & r \\
\hline Capsella bursa-pastoris var. pinnatifida & - & & - & & 14 & + & 6 & $r$ & 7 & + & - & \\
\hline Senecio jacobaea & - & & - & & 7 & + & 6 & r & 20 & $r-+$ & - & \\
\hline Anthoxanthum odoratum & - & & - & & 14 & + & - & & - & & 11 & + \\
\hline
\end{tabular}

Objaśnienia (Explanations): 1. Cerastio semidecandri-Androsacetum septentrionalis typicum: Kampus UAM -8 zdj. (Brzeg, Szygendowski oryg., tab. 1); Koziegłowy k. Poznania - 5 zdj., Janikowo k. Poznania - 2 zdj. (Brzeg, Janyszek 1998); 2. C.s.-A.s. thymetosum serpylli: Koziegłowy k. Poznania - 10 zdj. (Brzeg, Janyszek 1998); Kowalewek k. Konina - 2 zdj. (Brzeg 2017); 3. Myosotido strictae-Arabidopsietum thalianae: Kampus UAM - 9 zdj. (Brzeg, Szygendowski oryg., tab. $2+1$ npbl.); Janikowo k. Poznania - 1 zdj. (Brzeg, Janyszek 1998); Poznań Wola - 1 zdj. (Laudańska 1997: 65-66); Bruszczewo/Koszanowo k. Śmigla - 1 zdj. (Skrzypczak 2007, tab. 5, zdj. 5); Dąbrowice k. Koła - 1 zdj. (Sternik 2007, tab. 3, zdj. 1); Zielonagóra k. Obrzycka - 2 zdj. (Brzeg 2017); 4. Arenario-Sedetum acris: Kampus UAM - 9 zdj. (Brzeg, Szygendowski oryg., tab. 3); Poznań Antoninek - 2 zdj., Koziegłowy k. Poznania - 1 zdj. (Brzeg, Janyszek 1998); Marwice k. Gorzowa - 1 zdj. (Wojterska i in. 2016); Wiórek k. Poznania - 1 zdj. (Ratyńska 2001, tab. 118, zdj. 1); Bucz k. Śmigla - 1 zdj. (Skrzypczak 2007, tab. 19, zdj. 3); Kaplin, Kłodzisko, Prusim (Pojezierze Międzychodzko-Sierakowskie) 3 zdj. (Wojterska 2003, tab. 47, zdj. 1, 4, 5); 5. Erodio-Senecionetum vernalis: Kampus UAM - 7 zdj. (Brzeg, Szygendowski oryg., tab. 4); Koziegłowy k. Poznania - 3 zdj. (Brzeg, Janyszek 1998); Ziemin k. Śmigla - 1 zdj. (Skrzypczak 2007, tab. 5, zdj. 6); Pakawie k. Wronek - 1 zdj. (Wojterska 2003, tab. 45, zdj. 6); Niedźwiady (rynna jezior konińskich) - 2 zdj. (Wojterska i in. 2015); Lisów k. Słubic - 1 zdj. (Wojterska i in. 2016); 6. Sileno conicae-Cerastietum semidecandri: Kampus UAM - 6 zdj. (Brzeg, Szygendowski oryg., tab. 5); Poznań-Rataje - 3 zdj., poligon Biedrusko - 6 zdj. (Rakowski 1996, tab. 4, zdj. 1-4, 6-10); Koziegłowy k. Poznania - 1 zdj. (Brzeg, Janyszek 1998); Czerwonak i Radojewo k. Poznania - 2 zdj. (Ratyńska 2001, tab. 114); Osieczna - 
4 zdj. (Skrzypczak 2007, tab. 7); Skorzęcin k. Powidza - 1 zdj. (Zgrabczyńska, Brzeg 2009, tab. 1, zdj. 10); Ślesin - 4 zdj. (Wojterska i in. 2015).

Taksony sporadyczne z tabeli 6 (Sporadic taxa from Table 6): III: Agrostis vinealis $1\left(7^{+}\right), 2\left(8^{+}\right), 6\left(4^{+}\right)$; Armeria maritima ssp. elongata $2\left(8^{+}\right), 6\left(4^{+}\right)$; Astragalus arenarius $2\left(8^{+}\right)$; Carex arenaria $4\left(6^{+}\right)$; Cerastium arvense $3\left(7^{+}\right)$; Cladonia cervicornis ssp. verticillata $1\left(7^{+}\right)$; Cladonia floerkeana $1\left(7^{+}\right), 5\left(7^{+}\right)$; Cladonia mitis $2\left(8^{+}\right)$; Dianthus deltoides $5\left(7^{+}\right)$; Filago arvensis $6\left(4^{+}\right)$; Filago minima $3\left(7^{2}\right)$; Herniaria glabra $3\left(7^{1}\right), 4\left(6^{+}\right), 6\left(7^{1}\right)$; Leymus arenarius $2\left(17^{r-+}\right), 4\left(6^{1}\right)$; Potentilla impolita $1\left(7^{+}\right), 2\left(8^{+}\right)$; Sedum reflexum $1\left(7^{+}\right), 5\left(7^{+}\right)$; Sedum sexangulare $6\left(11^{+-1}\right)$; Teesdalea nudicaulis $3\left(14^{+}\right)$; Viola tricolor 5(7r); Vulpia myuros 5(7 $\left(7^{+}\right)$; IV: Allium oleraceum $4\left(6^{+}\right)$; Alyssum alyssoides $4\left(6^{1}\right)$; Carlina vulgaris $1\left(7^{r}\right)$; Centaurea scabiosa $2\left(8^{+}\right)$; Dianthus carthusianorum $2\left(8^{+}\right), 6\left(4^{+}\right)$; Erigeron acris $2\left(17^{+}\right)$, 4(6+); Homalothecium lutescens 2(8+); Plantago media 6(41); Silene otites $2\left(8^{+}\right), 4\left(6^{+}\right), 5\left(7^{+}\right)$; Verbascum lychnitis 4(6r), 5(7r); V: Anchusa officinalis 4(6 $\left.6^{+}\right)$; Anthriscus cerefolium 6(7r); Artemisia absinthium 6( $\left(7^{+}\right)$; Ballota nigra s.s. 5(7+); Bromus inermis 6(4+); Cichorium intybus 4(6r), 6(7r); Cirsium arvense 6(4r); Equisetum arvense $1\left(7^{+}\right), 2\left(8^{+}\right)$, $5\left(7^{+}\right), 6\left(4^{+}\right)$; Erigeron annuus $5\left(7^{+}\right), 6\left(4^{r}\right)$; Linaria vulgaris $2\left(8^{+}\right), 3\left(7^{+}\right), 5\left(13^{r-+}\right)$; Medicago $\times$ varia $5\left(7^{+}\right)$; Melilotus officinalis $1\left(7^{+}\right), 3\left(7^{+}\right), 4\left(6^{+}\right), 5\left(7^{r}\right), 6\left(4^{+}\right)$; Rubus caesius var. arvalis $2\left(8^{+}\right)$; Saponaria officinalis $5\left(7^{r}\right)$; Solidago canadensis $3\left(7^{+}\right)$; Tanacetum vulgare $4\left(17^{+}\right), 5\left(7^{+}\right), 6\left(4^{r}\right)$; Tussilago farfara $5\left(7^{+}\right), 6\left(4^{r}\right)$; Verbascum phlomoides $3\left(7^{r}\right), 4\left(6^{r}\right), 5\left(7^{r}\right)$; Verbascum thapsus $3\left(7^{r}\right), 5\left(7^{+}\right), 6\left(4^{r}\right)$; VI: Anthemis ruthenica $3\left(7^{1}\right), 6\left(7^{+}\right)$; Anthoxanthum aristatum $3\left(7^{+}\right)$; Bromus sterilis $6\left(7^{r-+}\right)$; Camelina microcarpa $5\left(7^{+}\right)$; Centaurea cyanus $6\left(4^{+}\right)$; Chamomilla recutita

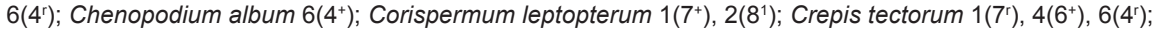
Descurainia sophia 6(4r); Eragrostis minor 5(7+); Euphorbia helioscopia 5(7r); Geranium pusillum 2(8r), 3(7r), 4(6r),

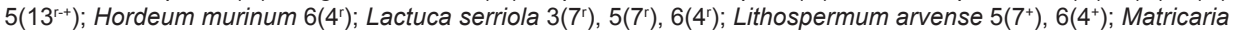
perforata $5\left(7^{+}\right), 6\left(11^{r-1}\right)$; Papaver rhoeas $3\left(7^{+}\right)$; Scleranthus annuus $3\left(7^{1}\right), 4\left(6^{r}\right), 5\left(7^{+}\right), 6\left(7^{r-+}\right)$; Senecio vulgaris

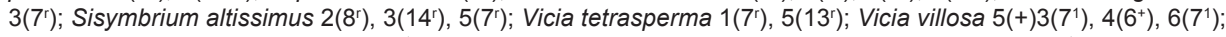
VII: Arrhenatherum elatius 3( $\left.7^{+}\right)$, 6(4 $\left.4^{1}\right)$; Cerastium holosteoides $3\left(7^{+}\right), 4\left(6^{+}\right)$; Crepis capillaris $4\left(11^{r-1}\right)$; Equisetum

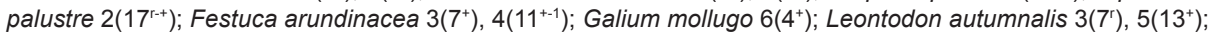

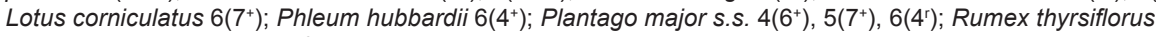
$1\left(7^{+}\right), 2\left(8^{+}\right), 3\left(7^{+}\right), 4\left(6^{+}\right), 5\left(7^{2}\right)$; Trifolium pratense $4\left(6^{+}\right)$; Vicia cracca $6\left(4^{+}\right)$. VII: Anthoxanthum odoratum $3\left(14^{+}\right)$, 6(11+); Acer platanoides 6(4r); Acer pseudoplatanus c 6(4r); Barbula convoluta 4(6 $\left.6^{+}\right)$; Betula pendula b/c 2(17r); Cardaminopsis arenosa $5\left(7^{+}\right)$; Cladonia coniocraea $1\left(7^{+}\right)$, 2(8+); Cladonia pyxidata $5\left(7^{+}\right)$; Cladonia sp. $6\left(4^{+}\right)$; Dicranum scoparium $3\left(7^{+}\right)$; Epipactis helleborine 2( $\left.8^{+}\right)$; Festuca tenuifolia $6\left(4^{2}\right)$; Funaria hygrometrica $5\left(13^{+}\right)$; Gagea pratensis $3\left(7^{+}\right)$; Holcus mollis $1\left(7^{+}\right)$; Hypnum cupressiforme var. lacunosum $1\left(7^{1}\right)$, $3\left(7^{+}\right)$; Medicago sativa 6(4r); Melampyrum pratense $3\left(7^{r}\right)$; Padus serotina b/c 3(7r); Peltigera canina 5( $\left.7^{+}\right)$; Polygonum amphibium fo.

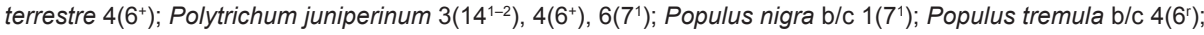
Quercus robur b/c 1(7r), 4(6r); Robinia pseudacacia c 6(4+); Rubus plicatus 3(7r); Sarothamnus scoparius b/c $6\left(7^{r-+}\right)$; Secale cereale $3\left(7^{r}\right)$; Solidago virgaurea $3\left(7^{1}\right)$, $4\left(6^{+}\right)$; Spergularia rubra $3\left(7^{+}\right)$; Tilia cordata c $6\left(4^{+}\right)$; Tortula subulata $6\left(4^{2}\right)$.

vernalis (9-15; zielone kwadraty), Arenario-Sedetum acris (24-32; żółte romby) oraz Sileno conicae-Cerastietum semidecandri (33-38; fioletowe kółka) tworzą na diagramie wyraźnie oddzielne skupienia, podczas gdy brązowe kwadraty (16-23), będące oznaczeniem zdjęć fitosocjologicznych z płatów Myosotido strictae-Arabidopsietum thalianae, nakładają się na dwa inne zespoły, co ukazuje ich pośredni charakter.

\section{Próba interpretacji uwarunkowań ekologicznych}

Obserwacje terenowe i uwagi zanotowane podczas wykonywania zdjęć fitosocjologicznych w żaden sposób nie pozwoliły na uchwycenie wyraźniejszej zmienności warunków siedliskowych badanych zespołów, może z wyjątkiem większego przywiązania płatów Cerastio semidecandri-Androsacetum septentrionalis do obrzeży zagajników sosnowych, Erodio-Senecionetum vernalis do położeń stokowych, a Myosotido strictae-Arabidopsietum thalianae do miejsc świeżo zerodowanych. Pewien pogląd na tę kwestię dają wyniki kanonicznej analizy zgodności (CCA). Na uzyskanym w wyniku tej analizy diagramie (ryc. 9) ujawniły się pewne preferencje wyróżnionych zespołów w stosunku do 


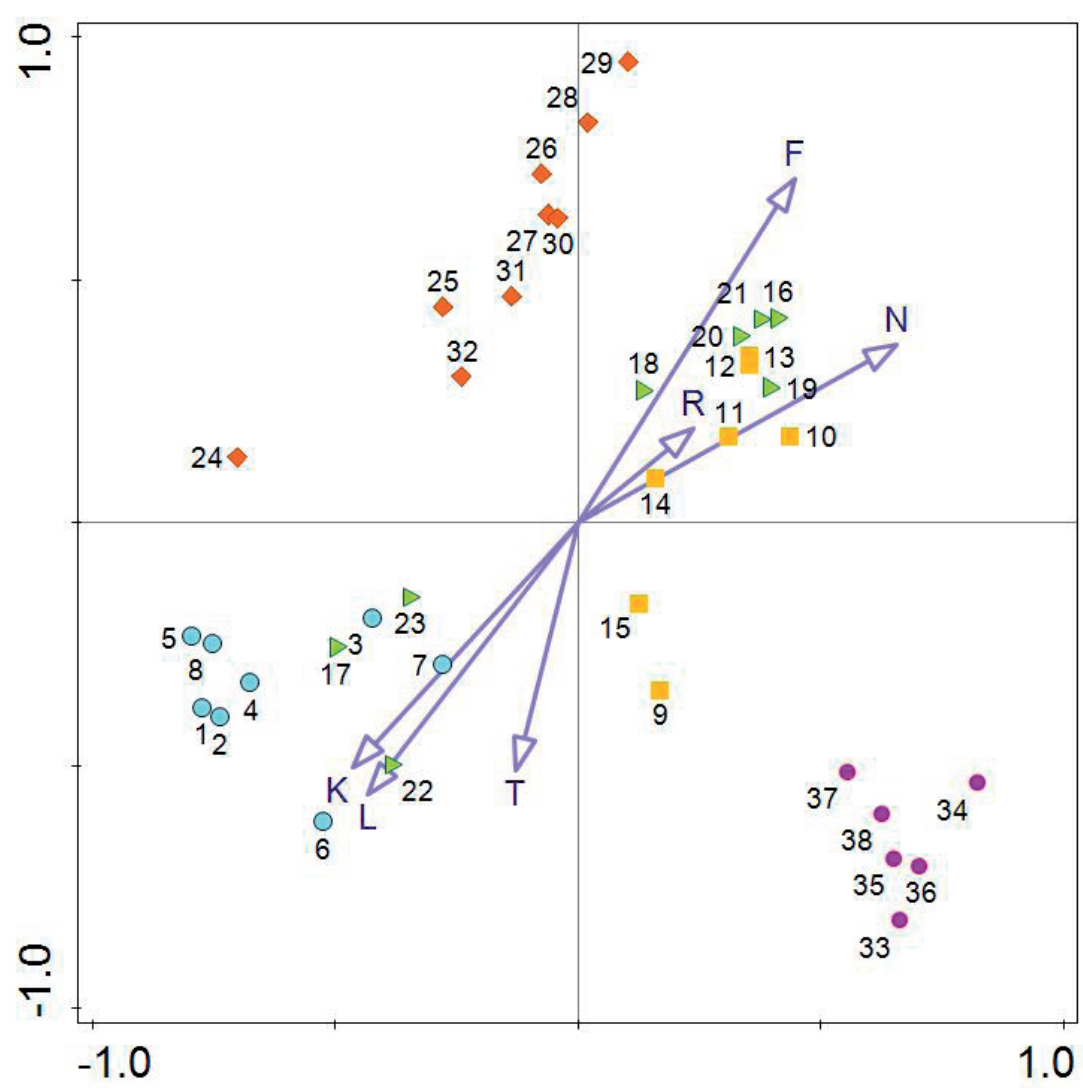

Ryc. 9. Diagram CCA dla pięciu badanych zespołów; do oznaczenia zmiennych środowiskowych użyto następujących skrótów literowych: L - wskaźnik świetlny, T wskaźnik termiczny, K - wskaźnik kontynentalizmu, F - wskaźnik wilgotności gleby, $\mathrm{R}$ - wskaźnik kwasowości podłoża, N - wskaźnik zawartości azotu w glebie; pozostałe objaśnienia w tekście

Fig. 9. CCA diagram for five examined associations; environmental variables are denoted as follows: $\mathrm{L}$ - light indicator, $\mathrm{T}$ - temperature indicator, $\mathrm{K}$ - continentality indicator, $\mathrm{F}$ - soil moisture indicator, $\mathrm{R}$ - soil acidity indicator, $\mathrm{N}$ - soil nitrogen content indicator; Cerastio semidecandri-Androsacetum septentrionalis (1-8; light blue circles), Erodio-Senecionetum vernalis (9-15; yellow squares), Myosotido strictae-Arabidopsietum thalianae (16-23; green triangles), Arenario-Sedetum acris (24-32; brown diamonds), Sileno conicae-Cerastietum semidecandri (33-38; violet circles)

sześciu czynników środowiskowych. Z większą wilgotnością oraz zasobnością podłoża w azot, w mniejszym stopniu z wyższym odczynem, pozytywny związek zdają się wykazywać płaty Erodio-Senecionetum vernalis (punkty 9-15; żółte kwadraty) i Arenario-Sedetum acris (24-32; brązowe romby), natomiast z wyższą termiką siedliska - fitocenozy Sileno conicae-Cerastietum semidecandri 
(33-38; fioletowe kółka) i Cerastio semidecandri-Androsacetum septentrionalis (1-8; jasnoniebieskie kółka). Ten ostatni zespół zdaje się wykazywać największe wymagania w stosunku do czynników światła i kontynentalizmu, a także powinowactwo do siedlisk kwaśniejszych, zdecydowanie unikając miejsc lokalnie wilgotniejszych i bogatszych w azot. Rozproszenie punktów reprezentujących centralny zespół Myosotido strictae-Arabidopsietum thalianae (16-23; zielone trójkąty) potwierdza szerokie spektrum możliwości jego występowania, a prawdopodobnie może być też powiązane $\mathrm{z}$ wewnętrzną zmiennością tego fitocenonu.

\section{DYSKUSJA}

Jak wykazano w artykule, pionierskie, antropogeniczne murawy ze związku Sileno conicae-Cerastion semidecandri nawet w warunkach lokalnych wykazują pełne spektrum zróżnicowania na zespoły, jakie podano dotychczas dla całej Polski niżowej w opracowaniu Ratyńskiej i in. (2010). Mimo powszechności występowania tego typu zbiorowisk i już długiego czasu, jaki upłynął od zasygnalizowania ich obecności (Głowacki 1984, 1988), dziwi fakt, że układy te później nie doczekały się obszerniejszego opracowania, a ich pozycja syntaksonomiczna nie została jednoznacznie ustalona. Tylko z Wielkopolski podano rozproszone i nie zawsze prawidłowo zinterpretowane materiały, które znalazły się jednak głównie w pracach niepublikowanych (por. objaśnienia do tab. 6).

W nowszych krajowych opracowaniach przeglądowych (Brzeg, Wojterska 1996, 2001; Brzeg, Rakowski 1997; Matuszkiewicz W. 2001) scharakteryzowano dwa znane wówczas zespoły z omawianej grupy, jednak umieszczone w dwóch osobnych, wikaryzujących geograficznie związkach: Sileno conicae-Cerastietum semidecandri w ramach submediterrańsko-subatlantyckiego Thero-Airion R.Tx. 1951 ex Oberd. 1957 (wykazanego tam pod nazwą Vicio lathyroidis-Potentillion argenteae Brzeg et M. Wojterska 1996 nom. superfl.) i Cerastio semidecandri-Androsacetum septentrionalis Głowacki 1988 ex Brzeg et M. Wojterska $2001 \mathrm{w}$ ramach subkontynentalnego Koelerion glaucae Volk 1931. W synoptyczej tabeli Brzega i Rakowskiego (l.c.) zauważono jednak podobieństwo florystyczne tych dwóch zespołów, wyrażające się wspólnym, znaczącym udziałem m.in.: Arenaria serpyllifolia, Berteroa incana, Bromus tectorum, Cerastium semidecandrum, Convolvulus arvensis, Erodium cicutarium, Erophila verna, Silene vulgaris, Trifolium campestre i Vicia lathyroides.

Porównanie zaprezentowanych $\mathrm{w}$ artykule danych oryginalnych $\mathrm{z}$ materiałami i koncepcjami syntaksonomicznymi Krauscha (1968), Celińskiego i Balcerkiewicza (1973), Kornecka (1974, 1978), Głowackiego (1975), Wiki (1975), Czyżewskiej (1992), Borysiak (1994), Passarge (1996), Brzega i Rakowskiego (1997), Sádlo i in. (2007) skłania do zaakceptowania zaprezentowanego przez Ratyńską i in. (2010) ujęcia, w myśl którego charakteryzowane typy muraw 
należy umieścić w jednym, szeroko ujętym związku Sileno conicae-Cerastion semidecandri. W ujęciu tym związek jest dobrze scharakteryzowany florystycznie i obejmuje psammofilne, po części pionierskie i efemeryczne, osiągające pełnię rozwoju w okresie wiosennym murawy na siedliskach przeobrażonych (wtórnych), budowane przede wszystkim przez dość szybko obumierające terofity. Jako jego gatunki charakterystyczne, osiągające w wymiarze regionalnym wyraźne optimum występowania w przynależnych do niego zespołach, przyjęto: Arenaria serpyllifolia s.s., Cerastium glutinosum, C. semidecandrum, Erophila verna, Holosteum umbellatum i Myosotis stricta, a jako wyróżniające Arabidopsis thaliana i Bromus tectorum. Uznawana przez Kornecka $(1974,1978)$ za Ch. All. Silene conica w Wielkopolsce jest jedynie wiernym gatunkiem charakterystycznym zespołu Sileno conicae-Cerastietum semidecandri. Wydaje się, że punkt ciężkości występowania w zbiorowiskach związku mają także Trifolium campestre i Medicago minima (por. tabele Kornecka l.c., Passarge 1996 oraz Brzega i Rakowskiego 1997). Prawdopodobnie wiele dalszych gatunków synantropijnych (np. Berteroa incana, Silene vulgaris czy Vicia hirsuta) można będzie uznać za wyróżniające związek. Za gatunek charakterystyczny żadnego zespołu murawowego, związku Sileno conicae-Cerastion semidecandri, a tym bardziej osobnego rzędu Arabidopsietalia thalianae (por. Passarge 1996; Sádlo i in. 2007) nie może być uznany, przynajmniej w Wielkopolsce, Arabidopsis thaliana, będący tam typowym chwastem segetalnym i osiągający wybitne optimum występowania w zespole Papaveretum argemones. $\mathrm{Z}$ kolei Erophila verna i Myosotis stricta, uważane za Ch. Ass. tego ostatniego zespołu (Brzeg, Wojterska 2001; Ratyńska i in. 2010), mogą być dla niego tylko gatunkami wyróżniającymi, podobnie jak Holosteum umbellatum. Trzeba się zgodzić z innymi autorami środkowoeuropejskimi, że są to gatunki muraw piaskowych.

Wyjaśnienia wymaga kwestia odrębności związków Sileno conicae-Cerastion semidecandri i Thero-Airion. Ten ostatni, w wąskim ujęciu, jako skupiający tylko murawy z gatunkami jednorocznych traw z rodzajów Aira i Vulpia oraz Nardurus lachenalii (por. Krausch 1968; Korneck 1974, 1978; Sádlo i in. 2007), jawi się w zasadzie tylko jako grupa zespołów, które mają własne, dobre gatunki charakterystyczne, natomiast bardzo trudno wskazać częściej występujące, wspólne i wierne Ch. All. Nie można bowiem do takich zaliczyć np. Filago minima i Teesdalea nudicaulis, które punkt ciężkości występowania mają raczej w murawach szczotlichowych związku Corynephorion canescentis, Ornithopus perpusillus, Scleranthus polycarpos czy Vulpia bromoides, które swe optima osiągają w poszczególnych zespołach (Głowacki 1975, 1988; Ratyńska i in. 2010), ani też Moenchia erecta, Sagina ciliata czy Trifolium striatum, pojawiające się jedynie sporadycznie i lokalnie. $Z$ kolei wymieniane, przy szerszym ujęciu związku Thero-Airion (=Vicio lathyroidis-Potentillion argenteae) w Polsce, jako jego dalsze Ch. All., Veronica verna i Vicia lathyroides, jak się okazało, należą do częstych składników zbiorowisk związku Sileno conicae-Cerastion 
semidecandri. Nie mają więc przypisywanego im waloru diagnostycznego. W szczególności Vicia lathyroides wykazuje, przynajmniej w regionie Wielkopolski, silny związek z murawami tego ostatniego związku.

W szerszym wymiarze terytorialnym wiele kontrowersji rodzi kwestia podziału całej klasy Koelerio-Corynephoretea na rzędy. Już Brzeg i Rakowski (1997) zanegowali zasadność wydzielania w Polsce rzędów Thero-Airetalia, Festuco-Sedetalia i Cerastietalia semidecandri, uzasadniając swój pogląd brakiem dobrych gatunków charakterystycznych tych wysokiej rangi jednostek syntaksonomicznych. Wszystkie niżowe murawy piaskowe umieścili w jednym tylko rzędzie Corynephoretalia canescentis. Stanowisko takie zostało zaakceptowane też przez W. Matuszkiewicza (2001). Ostatnio Sádlo i in. (2007) w monografii zbiorowisk murawowych Republiki Czeskiej ograniczyli się do podziału klasy Koelerio-Corynephoretea na sześć związków, nie podejmując szerszej dyskusji na temat przynależności tych związków do rzędów. Mimo braku przekonujących argumentów florystycznych wyróżnili jednak osobną, monotypową klasę piaskowych muraw kontynentalnych Festucetea vaginatae Soó ex Vicherek 1972, z jednym tylko zespołem i związkiem. Z analizy materiałów przedstawionych w cytowanych wcześniej monografiach środkowoeuropejskich wynika, że jedynym, obok Corynephoretalia canescentis, uzasadnionym florystycznie rzędem interesującej nas klasy może być wąsko ujęty rząd Sedo-Scleranthetalia Br. -B1. 1955. Obejmuje on acydofilne murawy płytkich gleb naskalnych, związane z obszarami górskimi. Taki rząd ma własne gatunki charakterystyczne, m.in.: Arenaria leptoclados, Erophila praecox, Gagea bohemica, Minuartia fastigiata et sp. div., Poa badensis, Sedum album, Sempervivum tectorum et sp. div., Seseli osseum, Teucrium botrys, Thlaspi perfoliatum, Thymus humifusus czy Veronica praecox, praktycznie zupełnie niespotykane na piaszczyskach niżowych. Nie wnikając w wewnętrzny podział tego rzędu, należy jednak zauważyć, że kompletnym nieporozumieniem jest umieszczenie w jego obrębie psammofilnych zbiorowisk niżowych z północno-wschodnich Niemiec, w tym związku Sileno conicae-Cerastion semidecandri (por. Passarge 1996).

O ile analiza składowych głównych (PCA), przeprowadzona na oryginalnych, lokalnych materiałach z terenu kampusu UAM Morasko w Poznaniu (ryc. 8), potwierdziła koncepcje syntaksonomiczne, przyjęte na podstawie tradycyjnych studiów tabelarycznych, o tyle próba interpretacji wpływu czynników ekologicznych na zróżnicowanie badanych zespołów przy użyciu metody CCA, z zastosowaniem tzw. liczb wskaźnikowych dała wyniki niejednoznaczne, czy po części nawet niezgodne ze spodziewanymi. Dotyczy to w szczególności zespołu Cerastio semidecandri-Androsacetum septentrionalis. Jego kombinacja florystyczna, według analizy CCA, wykazuje najwyższy stopień światłolubności, podczas gdy w terenie jego płaty, jako jedyne z badanych, lokowały się niemal wyłącznie w bliskim sąsiedztwie zadrzewień i młodych zapustów sosnowych, w warunkach częściowego lub okresowego zacienienia. Trudne do 
interpretacji, w odniesieniu do większości czynników, jest położenie na diagramie (ryc. 9) punktów odpowiadających przede wszystkim zespołom Arenario-Sedetum acris (którego kombinacji, wbrew obserwacjom terenowym, powyższa analiza zdaje się przypisywać większe wymagania wilgotnościowe) oraz Sileno conicae-Cerastietum semidecandri. Być może największą rolę w różnicowaniu się badanych zbiorowisk odgrywają czynniki inne niż analizowane, np. ich miejsce w zachodzących lokalnie procesach wtórnej sukcesji roślinności.

Obecność na kampusie uniwersyteckim szeroko zróżnicowanych muraw psammofilnych, jak i wielu innych typów fitocenoz, pochodzenia zarówno naturalnego, jak i antropogenicznego, ma duże znaczenie dla dydaktyki prowadzonej na Wydziale Biologii UAM. Na kwestię tę zwracali już uwagę Balcerkiewicz (2006) oraz Balcerkiewicz i Pawlak (2012).

\section{PODSUMOWANIE}

Antropogeniczne zbiorowiska muraw ze związku Sileno conicae-Cerastion semidecandri, charakteryzujące się znaczącym udziałem terofitów w składzie gatunkowym, stanowią rozpowszechniony, choć słabo zbadany typ roślinności rzeczywistej terenów przeobrażonych. Jego pozycja syntaksonomiczna wciąż nie została w wystarczającym stopniu ustalona. Stosunkowo liczne zdjęcia fitosocjologiczne, dokumentujące takie fitocenozy, pochodzą z obszaru Wielkopolski. W niniejszym artykule opisano murawy powyższego związku, występujące powszechnie na terenie kampusu UAM Morasko w Poznaniu - mieście zlokalizowanym w środkowej części wspomnianego regionu.

Badania terenowe przeprowadzono w latach 2015-2016. Oryginalny materiał obejmuje 38 zdjęć fitosocjologicznych wykonanych metodą Braun-Blanqueta. Zdjęcia te zestawiono w pięciu tabelach analitycznych (tab. 1-5) przy użyciu metod tradycyjnej ordynacji manualnej. Tabela synoptyczna (tab. 6), poza powyższymi danymi, zawiera również zdjęcia zaczerpnięte $\mathrm{z}$ prac innych autorów z regionu Wielkopolski i Ziemi Lubuskiej. W wyniku analizy tabelarycznej wyróżniono pięć syntaksonów w randze zespołu: Cerastio semidecandri-Androsacetum septentrionalis, Erodio-Senecionetum vernalis, Arenario-Sedetum acris, Myosotido strictae-Arabidopsietum thalianae i Sileno conicae-Cerastietum semidecandri, oraz dwa w randze podzespołu: Cerastio semidecandri-Androsacetum septentrionalis typicum i C.s.-A.s. thymetosum serpylli. Fitocenoz tego ostatniego nie stwierdzono na obszarze badań. Dla nowo opisanych jednostek podano oryginalną diagnozę syntaksonomiczną. Na badanym terenie największym bogactwem florystycznym cechują się płaty ErodioSenecionetum vernalis (średnio 37 taksonów w zdjęciu), natomiast najuboższe w gatunki są fitocenozy Cerastio semidecandri-Androsacetum septentrionalis (31), co nie w pełni odpowiada danym z reszty regionu (odpowiednio: 32 i 27). 
Zestaw danych oryginalnych poddano również analizie składowych głównych (PCA) i kanonicznej analizie zgodności (CCA). Analiza PCA potwierdziła centralną pozycję Myosotido strictae-Arabidopsietum thalianae w obrębie związku, a także florystyczną odrębność każdej z pozostałych badanych asocjacji. Wyniki CCA wskazują, że niektóre zbiorowiska mogą być związane z siedliskami lokalnie wilgotniejszymi, zasobniejszymi w azot i, w mniejszym stopniu, bogatszymi w zasady, podczas gdy kombinacja gatunkowa Cerastio semidecandri-Androsacetum septentrionalis zdaje się wykazywać wyższe powinowactwo względem miejsc o bardziej kontynentalnym mikroklimacie i korzystniejszych warunkach świetlnych.

W artykule krótkiej dyskusji poddano kwestie dotyczące pozycji syntaksonomicznej muraw ze związku Sileno conicae-Cerastion semidecandri, podziału całej klasy Koelerio-Corynephoretea oraz wpływu czynników środowiskowych na zróżnicowanie zbiorowisk analizowanego typu.

\section{LITERATURA}

Balcerkiewicz S. (2006): Kwietna łąka trzęślicowa Galio borealis-Molinietum (W. Koch 1926) Philippi 1960 w sąsiedztwie Collegium Biologicum w kampusie uniwersyteckim Morasko w Poznaniu. Bad. Fizjogr. nad Polską Zach., B, 55: 99-104.

Balcerkiewicz S., Pawlak G. (2012): Psammofilna murawa szczotlichowa Corniculario-Corynephoretum (R.Tx. 1928) Steffen 1931 nom. invers. na terenie kampusu uniwersyteckiego Morasko w Poznaniu. Bad. Fizjogr., B, R. III (B61): 85-92.

Borysiak J. (1994): Struktura aluwialnej roślinności lądowej środkowego i dolnego biegu Warty. Ss. 264. Wyd. Nauk. UAM. Ser. Biol., 52. Poznań.

Borysiak J., Stachnowicz W. (2003): Delimitacja obszarów środowiskotwórczych do projektu miejscowego planu zagospodarowania przestrzennego dla rejonu Morasko-Radojewo-Umultowo w Poznaniu. Przegl. Przyrodniczy, 14(3-4): 77-92.

ter Braak C. J. F., Šmilauer P. (2014): Canoco 5, Windows release (5.04). Software for multivariate data exploration, testing, and summarization. http://www.canoco5.com (dostęp: 15.05.2017).

Braun-Blanquet J. (1964): Pflanzensoziologie. 3. Aufl. Ss. 865. Springer-Verl. Wien-New York.

Brzeg A. (2007): O występowaniu w Wielkopolsce niektórych rzadkich lub mało znanych zbiorowisk synantropijnych. Cz. II: Salsolion ruthenicae Philippi 1971. Bad. Fizjogr. nad Polską Zach., B, 56: 71-89.

Brzeg A. (2009): O występowaniu w Wielkopolsce niektórych rzadkich lub mało znanych zbiorowisk synantropijnych. Cz. III: Saginion procumbentis R.Tx. et Ohba in Géhu et al. 1972. Bad. Fizjogr. nad Polską Zach., B, 58: 89-112.

Brzeg A. (2017): Materiały do znajomości zbiorowisk murawowych Wielkopolski. Z Zakł. Ekol. Rośl. i Ochr. Środ. UAM. Poznań (mskr.).

Brzeg A., Janyszek S. (1998): Zbiorowiska murawowe północno-wschodnich obrzeży aglomeracji Poznania. Z Zakł. Ekol. Rośl. i Ochr. Środ. UAM. Poznań (mskr.).

Brzeg A., Rakowski W. (1997): Uwagi do syntaksonomii muraw napiaskowych Polski. [W:] Wika S. (red.). Roślinność obszarów piaszczystych: 30-39 + tab. WBiOŚ UŚ, ZJPK. Katowice-Dąbrowa Górnicza.

Brzeg A., Wojterska M. (1996): Przegląd systematyczny zbiorowisk roślinnych Wielkopolski wraz z oceną stopnia ich zagrożenia. Bad. Fizjogr. nad Polską Zach., B, 45: 7-40. 
Brzeg A., Wojterska M. (2001): Zespoły roślinne Wielkopolski, ich stan poznania i zagrożenie. [W:] Wojterska M. (red.). Szata roślinna Wielkopolski i Pojezierza Południowopomorskiego: 39-110. Bogucki Wyd. Nauk. Poznań.

Celiński F., Balcerkiewicz S. (1973): Zespoły muraw psammofilnych w Wielkopolskim Parku Narodowym pod Poznaniem. PTPN, pr. monogr. nad przyr. WPN pod Poznaniem, 5(4): 1-32.

Czyżewska K. (1992): Syntaksonomia śródlądowych, pionierskich muraw napiaskowych. Monogr. Bot., 74: 1-174.

Ellenberg H. (1974): Zeigerwerte der Gefäßpflanzen Mitteleuropas. Ss. 97. Scripta Geobotanica, 9. Verl. E. Goltze KG. Göttingen.

Fałtynowicz W. (2008): Checklist of lichens and lichenicolous fungi of Poland. Preliminary version 1 September 2008. http: //www.biologie.unihamburg.de/checklists/lichens/europe/ poland 1.htm (dostęp: 15.05.2017).

Farat R. (1996): Klimat Poznania. Środowisko naturalne miasta Poznania. Urząd Miejski w Poznaniu, Wydz. Ochr. Środ. Poznań.

Farat R., Mager P., Pijewska M. (2004): Atlas klimatu województwa wielkopolskiego. Bad. Fizjogr. nad Polską Zach., A, 63: 209-229.

Głowacki Z. (1975): Zbiorowiska murawowe zachodniej części Wzgórz Trzebnickich. Ss. $104+$ tab. Pr. Opolskiego TPN, PWN. Warszawa-Wrocław.

Głowacki Z. (1984): Zbiorowiska murawowe zachodniej części Wału Trzebnickiego. Zesz. Nauk. WSR-P w Siedlcach, Ser. Przyr., 4: 157-176.

Głowacki Z. (1988): Zbiorowiska psammofilne klasy Sedo-Scleranthetea Wysoczyzny Siedleckiej i terenów przyległych na tle ich zasięgów. Ss. 122. Rozpr. Nauk. WSR-P. Siedlce.

Kampus Morasko (2017): https://pl.wikipedia.org.wiki/Kampus_Morasko (dostęp: 10.06.2017).

Klimko M., Bałuka B., Klimko W. (2008): Przyroda miasta Poznania. Wyd. Wydz. Ochr. Środ. Urzędu Miasta Poznania. Poznań.

Kondracki J. (1998): Geografia regionalna Polski. Ss. 441 + mapa. Wyd. Nauk. PWN. Warszawa.

Korneck D. (1974): Xerothermvegetation in Rheinland-Pfalz und Nachbargebieten. Ss. $196+$ tab. Schr. Reihe Vegetationskde., 7. Bonn-Bad Godesberg.

Korneck D. (1978): Klasse: Sedo-Scleranthetea Br.-Bl. 55 em. Th. Müller 61. Mauerpfeffer-triften, Sandrasen, Felsgrus- und Felsband-Gesellschaften. [W:] Oberdorfer E. (ed.). Süddeutsche Pflanzengesellschaften II: 13-85. Pflanzensoziologie, 10. G. Fischer Verl. Jena.

Krausch H.-D. (1968): Die Sandtrockenrasen (Sedo-Scleranthetea) in Brandenburg. Mitt. Flor.soz. Arbeitsgem., N. F., 13: 71-100 + tab.

Krygowski B. (1958): Krajobraz Wielkopolski i jego dzieje. Ss. 159. PWN. Warszawa.

Laudańska A. (1997): Roślinność murawowa na terenie stadniny koni na Woli w Poznaniu. Pr. magist. z Zakł. Ekol. Rośl. i Ochr. Środ. UAM. Poznań (mskr.).

Matuszkiewicz J. M. (1993): Krajobrazy roślinne i regiony geobotaniczne Polski. IGiPZ PAN, Pr. Geogr., 158: 5-107.

Matuszkiewicz W. (2001): Przewodnik do oznaczania zbiorowisk roślinnych Polski. Ss. 537. Wyd. Nauk. PWN. Warszawa.

Mirek Z., Piękoś-Mirkowa H., Zając A., Zając M. (2002): Flowering plants and pteridophytes of Poland. A checklist. Ser. Biodiversity of Poland. Vol. I. Ss. 442. W. Szafer Inst. of Bot., Polish Acad. of Sci. Kraków.

Ochyra R., Żarnowiec J., Bednarek-Ochyra H. (2003): Census catalogue of Polish mosses. Biodiversity of Poland. Vol. 3. Ss. 372. W. Szafer Inst. of Bot., Polish Acad. of Sci. Kraków.

Passarge H. (1996): Pflanzengesellschaften Nordostdeutschlands. I. Hydro- und Therophytosa. Ss. 298. J. Cramer. Berlin-Stuttgart.

Rakowski W. (1996): Zbiorowiska murawowe Obszaru Chronionego Krajobrazu „Biedrusko” koło Poznania. Pr. magist. Zakł. Ekol. Rośl. i Ochr. Środ. UAM. Poznań (mskr.).

Ratyńska H. (2001): Roślinność Poznańskiego Przełomu Warty i jej antropogeniczne przemiany. Ss. $466+$ tab. Wyd. Akad. Bydgoskiej im. Kazimierze Wielkiego. Bydgoszcz. 
Ratyńska H., Wojterska M., Brzeg A., Kołacz M. (2010): Multimedialna encyklopedia zbiorowisk roślinnych Polski ver. 1.1. Uniw. im. Kazimierza Wielkiego, Inst. Eduk. Technol. Inf. Bydgoszcz.

Sádlo J., Chytrý M., Černý T. (2007): Pionýrská vegetace písčin a mělkých půd (Koelerio-Corynephoretea). - Pioneer vegetation of sandy and shallow soils. [W:] Chytrý M. (ed.). Vegetace České republiky 1. Travinná a keříčková vegetace. - Vegetation of the Czech Republic 1. Grassland and Heathland Vegetation: 320-365. Academia. Praha.

Skrzypczak A. (2007): Roślinność ciepłolubna Pojezierza Leszczyńskiego. Pr. magist. z Zakł. Ekol. Rośl. i Ochr. Środ. UAM. Poznań (mskr.).

Sternik A. (2007): Roślinne zbiorowiska nieleśne w kompleksie dąbrów koło Dąbrowic w Nadleśnictwie Koło (wschodnia Wielkopolska). Pr. magist. z Zakł. Ekol. Rośl. i Ochr. Środ. UAM. Poznań (mskr.).

Weber H. E., Moravec J., Theurillat J.-P. (2000): International Code of Phytosociological Nomenclature. 3rd edition. Journ. of Veget. Sci., 11: 739-768.

Wika S. (1975): Roślinność zbiorowisk murawowych okolic Kamionny i Dormowa w powiecie międzychodzkim. Ss. 48. Pr. Kom. Biol. PTPN, 40. PWN. Warszawa-Poznań.

Wojterska M. (2003): Struktura krajobrazów roślinnych Pojezierza Międzychodzko-Sierakowskiego. Ss. 415. Bogucki Wyd. Nauk. Poznań.

Wojterska M., Brzeg A., Jasińska K. (2016): Importance of old rural areas of Lubuskie Lakeland and central Pomerania for maintenance of vegetation diversity. Biodiv. Res. Conserv., 43: 53-66 + unpublished data.

Wojterska M., Brzeg A., Szygendowski T. (2015): Roślinność rzeczywista siedlisk lądowych. [W:] Błoszyk J., Burchardt L., Chmiel J., Gąbka M. (red.). Wybrane problemy funkcjonowania przyrodniczego rynny jezior konińskich. UAM. Poznań (w druku).

Zarzycki K., Trzcińska-Tacik H., Różański W., Szeląg Z., Wołek J., Korzeniak U. (2002): Ecological indicator values of vascular plants of Poland. - Ekologiczne liczby wskaźnikowe roślin naczyniowych Polski. Ss. 183. W. Szafer Inst. of Bot., Polish Acad. of Sci. Kraków.

Zawadzka J. (2009): Charakterystyka fizjograficzna terenu Kampusu Uniwersytetu im. Adama Mickiewicza na Morasku w Poznaniu. Praca licencj. z Zakł. Ekol. Rośl. i Ochr. Środ. UAM. Poznań (mskr.).

Zawadzka J. (2015): Zbiorowiska ciepłolubnych ziołorośli ruderalnych ze związku Onopordion acanthii s.l. na terenie Kampusu Uniwersytetu im. Adama Mickiewicza na Morasku w Poznaniu. Praca magist. z Zakł. Ekol. Rośl. i Ochr. Środ. UAM. Poznań (mskr.).

Zgrabczyńska M., Brzeg A. (2009): Murawy psammofilne Powidzkiego Parku Krajobrazowego. Bad. Fizjogr. nad Polską Zach., B, 58: 73-88.

Żmudzka E. (2012): Wieloletnie zmiany zasobów termicznych w okresie wegetacyjnym i aktywnego wzrostu roślin w Polsce. - Long-term changes of thermal resources in the vegetative period and the active growth of plants in Poland. Woda Środ. Obsz. Wiej, 12: 377-389.

\section{PSAMMOPHILOUS SWARDS OF THE ALLIANCE SILENO CONICAE- CERASTION SEMIDECANDRI KORNECK 1974 IN THE AREA OF THE ADAM MICKIEWICZ UNIVERSITY MORASKO CAMPUS IN POZNAŃ}

\section{Summary}

Anthropogenic psammphilous swards of the Sileno conicae-Cerastion semidecandri alliance, characterized by a significant share of therophytes in their 
species composition, constitute a fairly widespread, yet poorly known type of vegetation, whose syntaxonomical status still hasn't been sufficiently explained. In Poland, relatively numerous records documenting such communities come from the Wielkopolska region. In the present paper the Sileno conicae-Cerastion semidecandri swards occurring commonly within the area of the A. Mickiewicz University Morasko campus in Poznan - a city located in the central part of the mentioned region - are described.

Field investigations were carried out in the years 2015-2016. The original material comprises 38 Braun-Blanquet relevés. As a result of traditional manual ordination procedures, they have been arranged in 5 analytical tables (Tab. 1-5). In a synoptic table (Tab. 6), aside from the mentioned data, relevés derived from other authors' studies from the Wielkopolska region are also included. Following the table analysis, five syntaxa in the rank of association: Cerastio semidecandri-Androsacetum septentrionalis, Erodio-Senecionetum vernalis, Arenario-Sedetum acris, Myosotido strictae-Arabidopsietum thalianae, Sileno conicae-Cerastietum semidecandri, and two in the rank of subassociation: $\mathrm{Ce}$ rastio semidecandri-Androsacetum septentrionalis typicum and C.s.-A.s. thymetosum serpylli, have been distinguished; phytocoenoses of the last mentioned syntaxon haven't been confirmed in the research area. For the newly described units: Cerastio semidecandri-Androsacetum septentrionalis typicum and C.s.A.s. thymetosum serpylli, an original syntaxonomical diagnosis has been given. In the studied area, the highest species richness can be attributed to the phytocoenoses of Erodio-Senecionetum vernalis (in average 37 taxa per relevé), while the floristically poorest are those of Cerastio semidecandri-Androsacetum septentrionalis (31), which doesn't entirely match the data from the whole region (32 vs. 27, respectively). The original relevé set has also been subjected to PCA and CCA procedures. As a result of the PCA, the "central" position of the Myosotido strictae-Arabidopsietum thalianae within the alliance, and the floristic distinctiveness of each one of the other examined associations as well, has been demonstrated. The CCA results suggest that some communities may be related to locally wetter, richer in nitrogen, and to a lesser extent - more base-rich habitats, whereas Cerastio semidecandri-Androsacetum septentrionalis shows a higher affinity towards sites experiencing a more continental microclimate and better light conditions.

Issues concerning the syntaxonomical position of Sileno conicae-Cerastion semidecandri swards, the division of the whole Koelerio-Corynephoretea class, and the influence of some environmental factors on the diversity of the examined community types as well, have been briefly discussed. 